NBER WORKING PAPER SERIES

\title{
ACCELERATING INFLATION AND THE DISTRIBUTION OF HOUSEHOLD SAVINGS INCENTIVES
}

Edward J. Kane

Working Paper No. $\underline{470}$

\section{NATIONAL BUREAU OF ECONOMIC RESEARCH 1050 Massachusetts Avenue \\ Cambridge MA 02138}

April 1980

\begin{abstract}
The research reported here is part of the NBER's research project on the changing role of Debt and Equity Finance in U.S. Capital Formation in the United States, which is being financed by a grant from the American Council of Life Insurance. Any opinions expressed are those of the author and not those of the National Bureau of Economic Research.
\end{abstract}




\section{Accelerating Inflation and the Distribution of Household Savings Incentives}

\section{ABSTRACT}

This study describes how accelerating inflation has led households in different economic and demographic classes to reallocate their "Éransactable savings." Cross-section data from the 1962 and 1970 surveys of Consumer Finances are used to estimate both the composition of accumulated household saving and prospective rates of return on this saving.

The paper shows that accelerating inflation has, in the presence of comprehensive ceilings on deposit interest rates, altered the savings incentives of different types of households. The effect has been to bias small savers toward leveraged investments in tangible assets (especially real estate) and large savers toward certificates of deposit and marketable bonds. Small savers with disadvantaged access to credit are simply victimized.

Our analysis helps to explain a number of anomalous features of the 19751979 macroeconomic recovery, particularly the dominant role of consumer spending, the unprecedented expansion of household debt, the boom in housing, and declining flows of household savings into deposit institutitons.

These data underscore the unintended consequences of trying to reconcile deposit-rate cellings with accelerating inflation. This combination of policies unpleasantly distorts the sectoral composition of spending and risk-bearing (crowding out some productive business investment) and aggrevates inequities in the distribution of income and opportunity.

Professor Edward J. Kane Ohto State University 1775 College Road Columbus, Ohio 43210 


\section{TABLE OF CONTENTS}

$\underline{\text { Page Number }}$

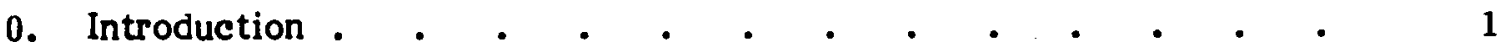

1. How Accelerating Inflation Has Hurt the Small Saver . . . . 4

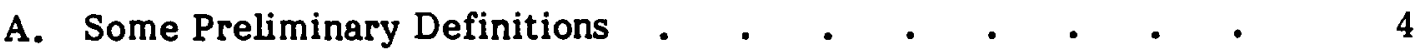

B. How Interest Ceilings Hurt Small Savers - • $\quad$ • $\quad$ - 5

C. Effect of Accelerating Inflation

on Financial Incentives Facing Small Savers $\quad$ - $\quad$ - $\quad$. $\quad$. 8

1. Unfavorable Movements in Marginal Tax Rates $\quad$. $\quad . \quad 9$

2. Unfavorable Movements in

Transactions Costs in Securities Markets . $\quad . \quad$. $\quad . \quad 10$

3. Discriminatory Adjustments in Deposit-Rate Ceilings . $\quad$ $\quad 10$

II. Behavior of Inflation and Interest Rates During the 1960s $\quad . \quad$ - $\quad 11$

A. Post-1966 Evolution of Deposit-Rate Ceilings . $\quad$ - . $\quad$ - 12

B. Investments in Real Estate

and Consumer Durables as Opportunities for Escapes . . . 13

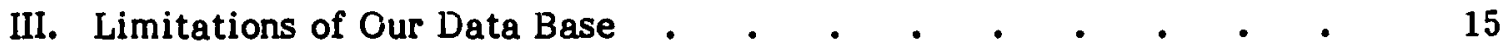

IV. Consolidated Balance Sheets for

Households in Different Age and Wealth Classes . $\quad . \quad$. $\quad . \quad 17$

A. Testing the Age Hypothesis: Consolidated

Balance Sheets for Households Classified By Age . $\quad$ - $\quad$. 19

B. Evidence on the Accuracy of

the Estimated Value of Owner-Occupied Housing • • • • $\quad 22$

1. Bias Due to Neglecting

Depreciation on Recently Purchased Homes . $\quad$ - $\quad$ - 22

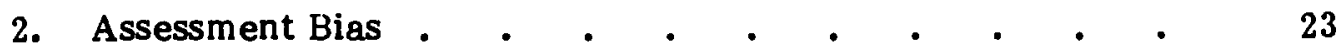


Table of Contents, Contd.

Page Number

C. Testing the Wealth Hypothesis: Consolidated Balance Sheets for Households Ranked By Their Net Transactable Wealth . . , . 24

V. Estimated 1970 Weighted-Average

Rates of Return for Each Age and Wealth Class $\quad$ - $\quad$ - $\quad$ - $\quad$ 25

VI. Testing the Minority Hypothesis:

Consolidated 1970 Balance Sheets and Estimated Portfolio Yields

For Families in Different Demographic Circumstances . . . $\quad$ - 29

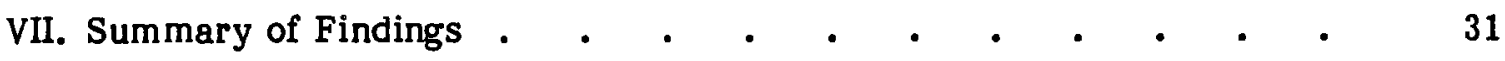

Tables • . . . . . . . . . . . . . . .

Footnotes $. \quad . \quad . \quad . \quad . \quad . \quad . \quad . \quad . \quad . \quad . \quad . \quad . \quad 53$

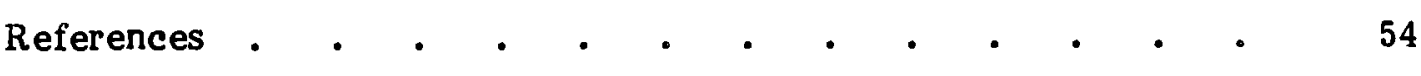


(Revised: February 1980)

\section{ACCELERATING INFLATION AND THE DISTRIBUTION OF HOUSEHOLD SAVINGS INCENTIVES*}

\section{Edward J. Kane}

Political rhetoric characterizes inflation as a high-ranking public enemy that society must band together to fight. But this view is exaggerated. Real-world inflation is never uniform in its effects. While some prices shoot up rapidly, other prices move hardly at all, and a few even decline. Uneven movements in prices cause inflation to affect the economic welfare of different people differently. The distribution of costs and benefits across the population works through the distribution of assets, debts, and labor skills. Just as some homes are protected against floods or earthquakes, some households possess skills and balance sheets whose net market values are protected against inflation.

Even when society as a whole is doing little to stop inflation, a venturesome household can neutralize inflation by suitably reallocating its wealth. It can do so by shifting its wealth (as far as transactions costs permit) into a collection of assets and liabilities whose overall rate of return promises to improve with anticipated and unanticipated increases in inflation. But most portfolios that protect against unanticipated inflation are speculative, in that they threaten to develop substantial losses if unanticipated deflation should ensue instead.

This study describes how, in the middle and late 1960s, households in different economic and demographic classes reallocated their "transactable savings" to cope with accelerating inflation. We define transactable savings to mean 
essentially noncontractual savings: savings that are not administered for households by insurance companies, pension funds, or the U.S. Social Security System.

We use cross-section data from the 1962 and 1970 Surveys of Consumer Finances to estimate both the composition of household portfolios of transactable savings and prospective rates of return on these portfolios. Our purpose is to cast some light on how accelerating inflation affects the savings incentives of different households and to map out resulting differences in the distribution of opportunities for accumulating personal wealth.

Our data set neglects claims on pension funds and wealth accumulated in collectibles, food inventories, and consumer durables that are not built into homes. Aggregate Flow of Funds data for the household sector developed by Cagan and Lipsey (1978) suggest that these unmeasured asset categories captured about half of the flow of net household saving between 1962 and $1970 .^{1}$ 'This proportion may be somewhat higher for younger and less-wealthy households.

As Cagan and Lipsey (1978) have shown, Flow of Funds data covering the household sector as a whole show virtually no change in balance-sheet ratios between 1962 and 1970. Moreover, although households' aggregate ratio of tangible to intangible assets rises sharply after 1972, Cagan and Lipsey argue that the increase can be attributed to capital appreciation on a relatively unchanging collection of assets, with no need to presume an active shift into inflationprotected assets. The research reported here indicates that the apparent passivity in aggregate household portfolio ratios conceals some important shifts in assetholding among wealth and age classes.

In the contemporary United States, the redistributive effects of . accelerating inflation can be properly understood only in conjunction with 
longstanding federal and state policies to promote homeownership and housing construction whose qualitative effects on savings incentives vary with the rate of inflation. These policies consist principally of income-tax preferences available to homeowners and a grab-bag of programs and political forces that act to slow inflation-induced increases in the nominal rate of interest charged on mortgage funds.

Our analysis features the concept of regulation-constrained portfolio balance. We show that, both to hedge inflation risk inherent in their nontransactable savings and to eke out a positive net real after-tax rate of return on their transactable funds, all but the wealthiest U.S. households found it advantageous to substitute investments in housing and investment real estate (and presumably also in collectibles, food inventories, and consumer durables) for traditional financial vehicles for savings. Influenced by transactions-cost and tax differentials, the nation's oldest and wealthiest households shifted their transactable wealth differently. They moved on balance out of home equity and traditional deposit accounts into certificates of deposit (CDs), marketable bonds, and equity in invest ment real estate.

Although both patterns of portfolio rebalancing make sense ex ante, the resulting balance sheets are noticeably riskier than the portfolios held by the corresponding sets of households in 1962. When in the 1970 s bond prices declined and stock values failed to increase with unanticipated inflation, real returns earned by most wealthy households fared badly ex post. These developments have left our nation's wealthiest households anxious and confused, particularly about the ability of common stocks to act as an inflation hedge. On the other hand, trends in housing prices have rewarded and reassured those generally less-wealthy investors who shifted heavily into real estate, especially those who dared to leverage themselves to the hilt. 
Disaggregating household behavior, particularly by wealth and age, helps to explain a number of puzzling special features of the 1975-79 macroeconomic recovery. These special features include: the dominant role of consumer spending; unprecedented increases in household debt; changing patterns of financial intermediaton; the improving quality of owner-occupied housing; and the growing speculative boom in residential real estate. Our analysis portrays each of these developments as a reasonable response to changes in the savings incentives facing households of different means.

I. HOW ACCELERATING INFLATION HAS HURT THE SMALL SAVER

\section{Some Preliminary Definitions.}

It is convenient to begin with some definitions. By "small savers," we mean households of modest means: families whose accumulated net transactable wealth is less that $\$ 10,000$. Returns on these savings may be expressed in several ways. Nominal rates of return are ratios of capital income to invested principal that make no correction for either anticipated or observed changes in the purchasing power of the sums to be lent and repaid. So-called market yields are invariably stated in nominal terms. Real rates of return are nominal rates less the rate of inflation anticipated or observed over the period during which the financial contract is held.

Anticipated inflation clearly affects the terms of loan contracts. Lenders want to negotiate a nominal rate of interest that exceeds the anticipated rate of inflation by what they take to be the "real" opportunity cost of their funds. In turn, borrowers can afford to pay nominal rates of interest that exceed the anticipated rate of inflation by the amount of the funds' perceived "real" productivity in the use they are going to serve. Hence, market interest rates tend 
to rise and fall with the level of anticipated inflation (Fisher, 1930). In addition, at any point in time an asset's nominal yield tends to rise with its subsequent inflation risk. Other things equal, the less perfectly an asset's nominal yield promises to rise with unanticipated future increases in inflation, the higher the nominal yield it must offer today (Fama and Schwert, 1977).

Explicit interest consists of returns to capital (coupon interest plus capital gains) that are paid, or are at least receivable in, the coin of the realm. Implicit interest covers services and other in-kind concessions that are of ten embodied in debt contracts. An asset's total rate of return is the sum of its explicit and implicit yields. Finally, an asset's net yield is its total rate of return minus any transactions costs associated with buying and selling the asset.

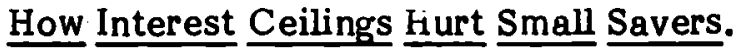

By raising expected rates of future inflation, observed accelerations in inflation tend to raise market rates of interest, although the response is not necessarily one-for-one and tends to be spread out in time. In nominal terms, rising market rates of interest mean improved new loan and investment opportunities for lenders. When deposit institutions are allowed to cornpete freely for deposit funds, pursuing these opportunities bids up deposit interest rates.

On the other hand, when deposit rates are held down by government-imposed ceilings, small savers cannot directly participate as fully in rising market rates as large savers can. This is because it is more costly per dollar for small savers to move their funds into securities markets. For small accumulations of wealth, the costs in yield equivalent of acquiring marketable securities are substantial. First, most small savers find it expensive simply to acquire sufficient financial sophistication to identify and track suitable investment opportunities. Second, the 
structure of dealer and broker transactions charges prevents low-value investments in open-market instruments from being economical. Third, because marketable instruments are seldom issued in small denominations, small portfolios of marketable instruments are almost always imperfectly diversified and subject therefore to excessive default and interest-rate risk.

In fully competitive markets, retail financial institutions (called financial intermediaries) develop to overcome these disadvantages by indirectly pooling household funds into amounts that can be invested economically (Gurley and Shaw, 1960). The pooling is indirect because these firms (commercial banks, thrift institutions, insurance companies, and mutual funds) sell their own debt to households and invest the proceeds for their own accounts. Intermediation occurs with respect both to denomination and to portfolio risk and is typically coupled with provisions for delivering additional services (e.g., depository institutions offer liquidity and transactions services to their accountholders). To the extent that the costs of providing nonpecuniary services are not recouped through fee income, these services may be treated as implicit interest payments. In competitive deposit markets, arrangements for paying implicit interest could in principle be sufficiently flexible to avoid efficiency losses from ceilings on explicit interest rates. But this condition is unlikely to be met in practice, especially in view of the asymmetric tax treatment of implicit and explicit interest receipts by U.S. households. Because households (unlike business firms) cannot deduct service charges from taxable income, implicit interest is tax-advantaged.

In competitive equilibrium, the value of implicit and explicit interest payments to intermediary customers must at the margin equal the risk-adjusted yield that competing intermediaries expect to earn on market instruments after meeting expenses and paying normal returns on capital. If a depository 
intermediary were to pay less interest than this, competitors would bid its depositors away. If a depository intermediary incurred excessive expenses (perhaps in the process of subsidizing a disproportionate amount of nonpecuniary services), either explicit interest or returns on capital would slide below competitive norms. Either event would cause pressure on the intermediary's management to restore operating efficiency.

Effective ceilings on deposit interest rates undermine the efficiency of intermediation. They force depository institutions to compete exclusively in terms of implicit interest. They are led to expand their packages of subsidized customer services, of ten in imaginative ways. Such services include merchandise premiums, longer operating hours, superfluous branch offices or electronic teller machines, and "free" checking. Unfortunately, the aggregate value of these services to individual customers is of ten far less than their cost to the depository institution. As individual customers attempt to make the best of what is for many of them a "bad" bargain, their use of undervalued services wastes economic resources.

Compared to the unregulated case, the efficiency of financial intermediation is also reduced by so-called disintermediation, which occurs when developing interest-rate differentials drive depositors to unregulated institutions and instruments. Whenever inflation drives open-market yields above the ceiling rates on deposits, higher-cost unregulated institutions (such as money-market mutual funds and credit unions) and unregulated instruments (such as repurchase agreements) are able to expand at the expense of traditional arrangements for intermediating household savings. 
Effect of Accelerating Inflation on Financial Incentives Facing Small Savers.

Financial theory holds that wealthowners' demand for any asset varies directly with the net after-tax real rate of return it offers relative to returns available on other assets. It is also supposed that the level of household saving increases with the net after-tax real rate available on traditional savings vehicles, although the evidence for this is far from conclusive (Boskin, 1978; Wachtel, 1977; Howrey and Hymans, 1978). During the last 15 years, unfavorable movements have occurred in marginal tax rates (which were only partly offset by increases in the standard deduction), in already-discriminatory dealer and broker transactions charges, and in the real (i.e., inflation-adjusted) values of interest-rate ceilings. Taken together, these changes have made it unrealistic for small savers to anticipate earning a positive net real rate of return on any collection of strictly financial assets. While financial instruments continue to offer implicit returns in the form of transactions, liquidity and diversification services, household savings invested in the types of financial assets available to nonwealthy households have shown reduced after-tax purchasing power with virtually every passing year.

To counterbalance the negative real after-tax rates of explicit return offered them by financial assets (and the roughly zero real returns accumulating on their nontransactable wealth), small savers have increased the weight of favorably taxed and inflation-protected real assets in their portfolios. To carry this off, they have had - as our survey data show - to supplement their accumulated savings with mortgage and instalment debt and to redirect their current savings into downpayments and debt service. Ironically, usury ceilings enacted in many states to improve small savers' access to credit probably interfered with this process. Theoretical and empirical analysis (Nathan, 1978) suggests that families who receive credit when usury ceilings are eiffective generally have above-average 
incomes and wealth. This occurs not just because such individuals are perceived as more creditworthy, though perceived creditworthiness may seem to dominate rejections of loan applications from members of minority groups (Sowell, 1975). What is of ten more important is that economically advantaged households can more easily increase deposit balances or meet increases in such up-front costs as higher downpayments or loan closing fees when lenders choose to exact implicit interest in such ways.

Unfavorable Movements in Miarginal Tax Rates. Because progressive income taxes are levied on nominal incomes, accelerating inflation increases the effective tax ra te that applies to every level of real income. However, legislated changes in the applicable tax structure provide some offset. As Table 2 shows, effective marginal tax rates were raised only for middle-income households. For example, using the implicit price deflator for GNP a taxable 1970 income of $\$ 30,000$ corresponds to $\$ 23,173$ in 1962 dollars. Using the tax schedule for joint returns with the same real (i.e., inflation-adjusted) taxable income at both dates, a taxpayer's marginal federal tax rate would be 40 percent in 1970 , but only 38 percent in 1962 . On balance, this taxpayer's average federal tax rate decreased from 28 percent in 1962 to 27 percent in 1970 . Because ordinary income tax rates apply to all nominal interest received, for middle-income households these changes increased the attractiveness of assets that yield either in-kind services that are not taxed at all or capital gains that are taxed preferentially.

In addition, the real value of dependent and standard deductions declined and, in many states, increases in state income taxes observed between survey dates further enlarged the wedge between before-tax and after-tax rates of return on nominal interest. 
Unfavorable Movements in Transactions Costs in Securities Miarkets. In the face of comprehensive interest-rate ceilings on traditional household savings instruments, secularly and cyclically accelerating inflation causes disintermediation of household funds into potentially riskier high-yielding open-market instruments. Disintermediation implies a larger flow of small-denomination trades offered to securities dealers and brokers. During the late 1960s, the first waves of inflation-induced disintermediation created clearings logjams in the backrooms of securities firms. To reduce the volume of individual trades to be processed, securities firms repriced their services in ways designed to discourage small individual trades. They instituted posted "ticket fees" on transactions of less than $\$ 100,000$. The practice of imposing a charge of $\$ 10$ to $\$ 20$ merely for writing up a small purchase or sale transaction spread through the industry. For many types of trades, securities firms also raised value-based odd-lot fees, transactions minima, and execution lags. Even though computerization of transactions and partial deregulation of the securities industry have lowered costs for large transactors, ticket fees on small trades have risen. Currently, they range between $\$ 25$ and $\$ 40$ per trade.

Discriminatory Adjustments in Deposit-Rate Ceilings. The larger is a household's wealth, the more alternative financial investment outlets it can economically consider. Larger savers can reallocate their portfolios to escape much of the ex ante burden that inflation and deposit-rate regulation would otherwise place on them. In contrast, poor households' principal avenue of adjustment is to cut back on their savings, a response that spreads the burden onto their future standard of living.

Larger savers' differential ability to escape deposit-rate ceilings explains why regulators have over time adapted the ceilings to permit deposit institutions to 
offer differentially higher interest rates to larger savers who can not be put off by high minimum denominations or punitive penalties for early withdrawal of timedeposit funds. Restrictions on minimum denomination and early-withdrawal penalties have been the cutting edge of a regulatory strategy of enabling deposit institutions to pay near-market interest rates to interest-sensitive depositors without raising yields offered to interest-insensitive customers.

\section{BEHAVIOR OF INF LATION AND INTEREST RATES DURING THE 1960s}

Table 1 shows that long-term interest rates rose throughout the 1960s, with the rate of increase accelerating sharply (along with the rate of inflation) in the last half of the decade. For calendar-year holding periods, the last two columns report ex post returns on bonds and stock. From year to year, these ex post returns vary sharply.

Let us interpret the twin 1966 shocks of accelerating inflation and comprehensive deposit-rate ceilings as a joint experimental "treatment" and inquire how the treatment affected interest-rate spreads. Until 1966 when federal deposit-rate ceilings were first extended to savings accounts at savings-and-loan associations (S\&LS) and mutual savings banks (MSBs), mean S\&L deposit rates tended to fluctuate above the average level of yields on Treasury bills, roughly tracking the average yield on long-term Treasuries.

Subsequently, Treasury yields averaged steadily higher than S\&L deposit rates. Whether this benefited mortgage borrowers is debatable, since even in the face of deposit-rate ceilings, mortgage rates regularly exceeded yields on longterm Treasuries, with the spread fluctuating within the same bounds that applied in the early 1960 s.

From 1966 forward, high interest rates on new mortgages offered unusually good earnings spreads for mortgage lenders. However, federal of ficials feared that 
open competition for savings funds would bankrupt older S\&Ls and MSBs that had to carry lots of low-rate mortgages on their books. With free competition, higher deposit rates would have to be paid on all accounts, while competitive mortgage rates could be earned only on current loans. Institutions holding substantial proportions of older low-rate mortgages would experience negative overall cash flows. Alternatively, one could say that higher current interest rates reduced the market value of many thrifts' seasoned long-term assets enough to exhaust their previously accumulated net worth. Restrictions on S\&L and MSB deposit interest were introduced to prevent newer firms from ruining the older ones. To keep commercial banks at a disadvantage, ceilings for thrifts were initially set $\mathbf{5 0}$ basis points above those that applied to commercial banks. (This "differential" has since narrowed to 25 basis points.) Federal authorities conceived the system of ceilings as a temporary stopgap measure, intended to avert an immediate threat of financial panic and to avoid temporarily destablizing the flow of inortgage credit and homebuilding activity. They sought to assure specialized mortgage-lending institutions a positive net cash flow by locking in an above-market profit margin on new lending to offset the slim (or negative) spread on old lending, presumably only until interest rates turned down again cyclically.

$\underline{\text { Post-1966 Evolution of Deposit-Rate Ceilings }}$

Once the ceilings were in place, their justification broadened. In repeated battles over proposed legislation, a coalition of the thrift, labor, and construction lobbies has been able to defeat subsequent attempts to remove the ceilings. Since 1966, the large and cyclically fluctuating spread between open-market yields and passbook rates has accentuated cyclical disintermediation and reduced the flow of savings to these institutions during most of the cycle. 'To minimize the disruption, authorities have undertaken a series of additional actions. Regulatory officials 
adopted a strategy of restructuring deposit-interest ceilings in ways that promised to lessen the disintermediation without greatly increasing costs on interestinsensitive funds. Repeated restructurings have developed a series of deposit instruments that - by making the maximum interest payable on any type of deposit account vary directly with its maturity and/or minimum denomination - allow depository institutions to offer higher interest rates to interest-sensitive customers without extending higher payouts to interest-insensitive ones. Although large CDs are now completely exempt from regulation, between 1966 and early 1970, even large CDs (though treated preferentially) were subject to ceilings. After January 21,1970 , interest was unfettered for certificate-of-deposit accounts of less than 90-days maturity and at least $\$ 100,000$ in minimum denomination.

To make its own securities less competitive with thrift deposits, the Treasury held interest rates on U.S. Savings Bonds well below those on marketable securities of similar maturity: at 4.25 percent until December 1969 , when they were raised to only five percent. The Treasury also acted in February 1970 to raise the minimum denomination of Treasury Bills from $\$ 1,000$ to $\$ 10,000$. Knowledgeable small savers had increasingly placed noncompetitive bids in $\$ 1,000$ and $\$ 5,000$ units, winning a larger and larger proportion of the total amounts awarded in the Treasury's weekly Bill auction (Mullineaux, 1973).

Investments in Real Estate and Consumer Durables as Opportunities for Escape.

During the post-1966 era, for households of modest means the inflationadjusted after-tax rate of return has been negative on the few financial assets their transactable wealth permits them to buy. Even in the twenty-percent tax bracket, a 5.25 percent return on passbook savings yields only 4.20 percent after taxes. In the thirty-percent bracket, the after-tax yield falls to 3.68 percent. It is 
hard to remember when the rate of inflation in product prices did not exceed these low rates of return. This means that savings invested in these assets have less real value with each passing year.

In the absence of government-enforced ceilings on deposit interest rates, market forces would have pushed financial-institution deposit rates up at least enough to promise low-bracket depositors a small anticipated net yield. With deposit-rate ceilings in place and transactions costs keeping small savers out of bond and stock markets, many households have found that real-estate assets offer their transactable savings the best available protection against inflation-induced erosions in purchasing power. Real estate ownership has been a traditional goal for Americans and returns on real property have been taxed much more favorably than returns on financial assets. Federal tax treatment of a property's capital income is especially generous for owner-occupants. Real estate gained attractiveness under comprehensive deposit-rate ceilings because well-developed mortgage markets provided a convenient vehicle for small savers to leverage their modest saving enough to cover the purchase price of a residence or rental property. Institutional arrangements do not exist to let them borrow so easily to purchase stock shares or fixed-interest securities. Households dealing with dealers and brokers must maintain margin accounts and pay one or two points over the broker-dealer interest rate for margin credit.

Ironically, restrictions on deposit interest have driven small savers increasingly into debt. Lacking enough wealth to invest directly in diversified round lots of marketable bonds and stocks and prevented by law from enjoying the full fruits of indirect investments in securities markets made by means of deposit accounts, they have turned to investing in real assets, supplementing their savings as necessary via mortgages and instalment loan contracts. With interest expense 
tax-deductible, real after-tax rates on loans made to support tax-favored investments seem unusually low.

Although this explanation is still not widely appreciated, small savers' efforts to protect their transactable wealth from being eaten away by artificially low deposit rates provide the motive force both for declines in recorded ratios of deposit-institution inflows to personal income and for an ongoing speculative boom in housing. In this way, deposit-rate ceilings have reinforced the secular inflation in housing costs and, by discouraging the flow of middle-income households' savings into strictly financial instruments, reduced the pool of savings available for new business investment too. Even though deposit-rate ceilings were intended to promote housing activity, authorities by no means meant to push it so assiduously or at such a high cost in macroeconomic destabilization.

\section{LIMITATIONS OF OUR DATA BASE}

Although the University of Michigan's Survey Research Center surveyed consumer finances throughout the 1960s, only the 1962 and 1970 survey questionnaires develop detailed information on household balance sheets. ${ }^{2}$ Fortunately, the two years lie symmetrically four years before and four years after what we can call the twin economic-policy "crimes of '66." As we did with interest-rate spreads, we propose to interpret the twin economic-policy shocks of accelerating inflation and the spread of deposit-interest ceilings to thrift institutions as an experimental "treatment" and to view survey data collected in the two years as representative samples of pre-treatment and post-treatment values of household income and balance-sheet variables.

Table 3 lists the particular survey variables investigated in this study. Unfortunately, assets are not valued on a consistent basis. Respondent family units were requested to furnish face values for bonds but to estimate market values for 
stocks and investment real estate. They were asked to estimate the "present value" of owner-occupied real estate (which we call homes) if they had resided there during the second calendar year preceding the year of the survey; otherwise they were asked merely to supply the home's purchase price. No matter how accurately they may be able to value their assets, secretive people or families whose members had reason to conceal assets from each other would have an incentive to underreport their holdings. Forgetfulness would cause underreporting, too. On the other hand, a desire to impress interviewers might tempt some respondents toward boastful overstatement.

Clearly, as compared to contemporaneous transactions values, estimates gathered in this way should have some systematic biases and should be more accurate for some asset categories than for others. For example, information needed to estimate the value of a household's stock portfolio is more readily accessible than that needed to appraise real estate. When housing prices are rising especially quickly, household estimates may tend to lag market values. As discount instruments, the values of unmatured U.S. Savings Bonds or Treasury Bills would be consistently overstated. Similarly, the generally upward trend of interest rates in the 1960s leads us to suspect that the market value of Other Bonds would on average fall short of face value. The reader should keep these difficulties in mind in interpreting our results.

Even in our two focal years, values for most types of what we call "nontransactable" assets and most debts were not reported at all. A few variables were reported in one year only. As Table 3 indicates, across the two years some variables are defined differently or are available in different detail.

Whatever one does to correct for these conceptual difficulties, one should also recognize that (precisely because high-income sample cells are small in 
absolute size) SCF samples deliberately over-represent high-income families and that SCF data tapes required careful editing to adapt them to our use. A few observations appear more than once on SCF data tapes. Occasional overflows occur in capital income and in individual assets, while in the 1970 survey partially incomplete reports pose some difficult problems. ${ }^{3}$ In particular, differences in the accuracy and completeness of respondent reports across conventional income and age classes change the representativeness of our samples relative to the population of U.S. households. Omissions and overflows should occur predominantly for households whose incomes and wealth are high, and result in an understatement of assets held by these groups. This measurement bias partly of fsets the sampling bias Survey Research Center personnel created by oversampling high-income households.

\section{CONSOLIDATED BALANCE SHEETS FOR HOUSEHOLDS IN}

DIFFERENT AGE AND WEALTH CLASSES.

In analyzing SCF data, we seek to identify how average asset-holding patterns differ with household income, transactable wealth, and the age, sex and race of the household head. Our principal focus is to determine the extent to which households in different economic and demographic circumstances shifted their transactable wealth among three classes of assets for which survey measurements exist:

1. Equity in real estate: defined as the difference between the value of investment real estate and owner-occupied housing (i.e., "homes") and the dollar amount of household debt secured by these properties;

2. Regulated financial assets: deposits and U.S. Savings bonds;

3. Unregulated financial assets: stocks, marketable bonds, and mutual funds. 
The purpose of the exercise is to investigate how the combined burdens of inflation and interest-rate ceilings are distributed across the population of U.S. households. We are concerned particularly with determining how these burdens are distributed across different types of families and how they have affected the mix of debt and equity assets in household portfolios.

Given the structure of income taxes, transactions costs and interest-rate ceilings, a household's ability to take advantage of regulation-exempt and taxavoiding savings opportunities may be expected to increase with its income (the "income hypothesis") and its transactable wealth (the "wealth hypothesis"), and to be influenced by its place in the life cycle (the "age hypothesis") and possible membership in minority groups (the "minority hypothesis"). By analyzing crosssection data on earnings, assets, debt and demographic characteristics collected in the 1962 and 1970 Surveys of Current Finances, the rest of this paper develops evidence consistent with a more precise formulation of each of these hypotheses.

Looking backward from 1979, it should be clear that ex post the big losers from accelerating inflation have been family units possessing large amounts of stock or "regulated assets" (deposits and U.S. Savings bonds) and those who did not own any real-estate assets at all. While wealthy households tend to be heaviest in stock, households that fit the rest of this profile turn out to be drawn disproportionately from the ranks of the old, the black, the female, the poor, and the young. Particularly in competing for mortgage loans, these groups are traditionally disadvantaged (Sowell, 1975). Moreover, with accelerating inflation, depositinterest ceilings heighten that disadvantage by driving up both the cost of housing and the demand for mortgages by other groups, while reducing the disadvantaged families' ability to accumulate the financial wherewithal to make an acceptable downpayment. 
Testing the Age Hypothesis:

\section{Consolidated Balance Sheets for Households Classified by Age}

Survey data depicting the composition of household assets indicate that between 1962 and 1970 the combination of accelerating inflation and deposit-rate ceilings has markedly changed the age distribution of real-estate ownership. This is shown in Table 4. Even as early as 1970 , households whose heads were less than 55 years in age had sharply increased the proportion of their accumulated savings held as equity in real estate, while older households had shif ted their funds out of

both real estate equity ${ }^{4}$ and "regulated financial assets" (deposits and U.S. savings bonds) into "unregulated financial assets" (stocks, marketable bonds, and mutual funds). Moreover, within their holdings of regulated assets, older households moved funds from other categories into certificates of deposit (CDs). In 1970, survey households whose heads were 55 or older owned approximately 55 percent of reported net transactable wealth, but 75 percent of total CDs, deposits, and stockmarket investments and 85 percent of marketable bonds. In 1962, this age group owned approximately 40 percent of respondents' net transactable wealth, and (except that they held only 15 percent of marketable bonds) allocated their funds fairly evenly across individual asset categories.

Presumably, older households find the in-kind return on housing less valuable as their children grow up and set up households of their own. However, they could afford economically to undertake these reallocations because they are on average large savers. Also at issue are the development of experience and efficient patterns for accumulating and decumulating wealth to smooth consumption over the life cycle. Our interpretation of these data implicitly attributes observed 
changes in portfolio distributions between 1962 and 1970 to differences in the ability of households of different ages to protect themselves both against increases in inflation and inflation risk and against unfavorable regulatory developments in financial markets. We simply presume that 1962 portfolio patterns are determined predominantly by life-cycle considerations. However, since the 1962 survey was taken about a year into a cyclical recovery and the 1970 survey at the beginning of an economic decline, cyclical influences probably affect the results, too. During the months of the 1962 survey, unemployment was cyclically high but falling. In 1970, unemployment was low but rising. Although aggregate unemployment rates were not greatly different, unemployment among males aged 20 to 24 averaged 11.2 percent in the 1962 survey months and only 7.7 percent during the 1970 interview period. The cyclically poorer labor-market outlook in 1962 may well have made some young households temporarily hesitant to undertake the responsibilities of homeownership.

However, young households' dramatic increase in the proportions of their transactable wealth placed in regulated assets and real-estate equity seems far too large to attribute to this small difference in age-class unemployment rates. In 1962 , only 6.2 percent of households whose heads were under age 25 owned their own residences, but by $1970,20.3$ percent of households in the counterpart age class were homeowners. In 1970 , the youngest age class quadrupled the portfolio weight carried by its 1962 counterpart. (Even if we eliminate as an outlier the wealthiest household in the 1962 age-class sample, the 1970 portfolio weight for home equity is still 2.5 times its 1962 value.) Because households in the youngest age class had generally smaller families in 1970 than in 1962 (so that they presumably found the continuing services of a given living space less productive), they must have anticipated substantial future appreciation in housing prices to 
justify this allocational pattern. It is possible that this inflation-spawned increase in the propensity of young families to undertake leveraged homeownership reflects as well a generational difference in both borrowers' and lenders' attitudes toward risk-bearing. The young have to live with the consequences of accelerating inflation over a longer economic horizon than anyone else. In the face of contemporary inflation, Table 5 indicates that modern lending officers and wouldbe young borrowers have proved less inhibited psychologically by conventional attitudes about the alleged "prudence" of "staying out of debt." But, adopting plausible assumptions about prospective yields on alternative assets, we show in section $\mathrm{V}$ that even these massive portfolio shifts were insufficient to bring the prospective 1970 portfolio rate of return for this age class up to the level earned by older households.

Table 5 indicates that, whatever assets are ultimately supported by real-estate debt (Arcelus and Meltzer, 1973), most age classes (especially the youngest) carry in 1970 a larger proportion of this debt in their portfolios. Even more important, the observed reallocation of the housing stock among age groups has shifted ownership on balance from families who traditionally carry low debt ratios to younger households who show much higher ratios of mortgage debt to home equity and transactable wealth. This explains how the aggregate proportion of home equity to net transactable wealth can actually decline between the survey dates.

To show that our results measure a true generational difference, we can reclassify the data to emphasize that the cohorts of households belonging to each age group differ substantially between survey dates. Table 6 resets the boundaries of the 1962 age classes to let us compare portfolio weights for the same age cohorts at each survey date. This table makes it clear that household heads who 
are less than 25 years old in 1970 were not even sampled in 1962 . Otherwise, it confirms the age-class and generational paterns of asset accumulation and decumulation inferred from Table 4. Further analysis (not reproduced here) indicates that allowing for the effects of housing-price appreciation on each age cohort's 1962 investment in housing does not change the qualitative pattern of age-class portfolio reallocation.

Evidence on the Accuracy of the Estimated Value of Owner-Occupied Housing

In valuing household real-estate investments, the two main sources of measurement error are: (1) reliance on self-assessment and (2) the neglect of price appreciation on homes purchased in the year preceding the survey date. These errors are worrisome because they threaten to prove reinforcing. Taken together, they might cause a serious understatement of home equity.

Bias Due to Neglecting Depreciation on Recently Purchased Homes. Turning to the second issue first, Table 7 develops information on the four percent of 1970 survey respondents who had purchased their homes in 1969. The U.S. Commerce Department estimates that the average sales price of houses sold in 1969 increased 4.9 percent, with the rate of price increase greater in the first half of the year than in the second. In the first half of 1970 , prices increased another 0.7 percent. Since the survey instrument did not ascertain precisely when in 1969 individual homes were acquired, our calculations assume that by the survey date each of these homes had experienced six months' appreciation in 1969 (2.5 percent) plus a further 0.7 percent in 1970. Except in the youngest age class, the effect of accounting for this appreciation is negligible. Even for this class, when raw data are employed, the portfolio weight for home equity rises only by 1.2 percentage points. 
Assessment Bias. Respondents' self-assessments of the value of their homes may be inaccurate because homeowners who do not actively participate in housing markets have a poor idea of trends in house prices. In Table 8, we develop evidence by which to investigate whether, given the inflationary surge in house prices during the 1960s, homeowners who had occupied the same residence for various periods of time consistently undervalued their property in 1970 .

To do this, we report data on housing values at each survey date by the year in which homeowners first occupied their homes. We extrapolate the values estimated in 1962 forward to 1970 , using cumulative rates of increase observed in average housing prices. These projections are meant to be compared with roughly parallel assessments quoted by respondents in 1970 .

Unfortunately, the data do not permit precise comparisons. First, 1962 and 1970 SCF data tapes aggregate reported years of occupation into largely noncomformable intervals. Hence, the two data sets place different boundaries on the date-of-occupation variable. Second, since indices of average housing prices are available only from 1963, the first observations on year-to-year changes in housing prices date from 1964. To fill in the gap for 1962 and 1963 , we used movements in the GNP Price Deflator to proxy the rate of housing-price inflation. Finally, since data published on housing prices cover only new houses, we need to consider whether on average homeowners upgrade older houses to incorporate most of the comforts being built routinely into newer structures. 5 What we call our "low projections" track changes in the value of a hypothetical house whose attributes are fixed. Our "high projections" track changes in the value of the specific types of houses constructed and sold in each year.

Since the assessments made by respondents in 1970 average near the high projections of comparable 1962 estimates, our data suggest that (at least in the aggregate) self-assessment is not a serious source of downward bias. 
Testing the Wealth Hypothesis: Consolidated Balance Sheets

for Households Ranked By Their Net Transactable Wealth

For both survey dates, Table 9 reports consolidated portfolio weights for households grouped by their decile of net transactable wealth. The observed changes in portfolio patterns by wealth class confirm earlier analyses (Kane, 1970 and 1977) of post-1966 disintermediation. Sophisticated households with sizeable amounts of savings can and do shop among a variety of assets. By 1970, they could rearrange their financial-asset portfolios to lessen the burden that deposit-interest ceilings would otherwise have placed on them. Moreover, the longer the ceilings remained in force, the more fully financial markets and institutions could adapt to help them. The rapid growth of money-market mutual funds and credit unions and the development of small-denomination bonds by large municipal and corporate issuers - provide examples of this adaptation. Relaxing the ceilings on minimumdenomination and longer-maturity certificates of deposits allows the nation's wealthier households to earn higher explicit deposit rates at banks and thrif $t$ institutions than ordinary families can. For small savers, possibilities for adapting their financial portfolios are severely limited and have been further compressed by government action to reduce disintermediation, notably the 1970 increase in the minimum denomination of U.S. Treasury Bills. Providing they can obtain debt financing, small savers lessen the burden of low ceiling rates of interest on regulated financial assets principally by investing directly in homes, investment real estate, and consumer durables.

Hence, in Table 9, between 1962 and 1970 we see that through the sixth decile portfolio weights for regulated financial assets fall while the weights for real-estate equity rise. Although households in the seventh decile of wealth show much the same portfolio weights at both dates, between 1962 and 1970 savers in 
the eighth and ninth deciles undertook some marked shifts in the allocation of their transactable wealth. Looking simultaneously at Table 10 which develops more detailed data on financial assets, we see that these households moved funds proportionately out of investment real estate, common stocks, checking accounts and savings bonds into high-rate CDs and (to a lesser extent) into other savings accounts.

Families in the highest-wealth decile (whose actions loom very large in aggregate figures), reduced their home equity and moved out of every type of regulated asset except CDs. Unlike middle-wealth households who decreased the portfolio weight for common stock or low-wealth households who increased it, the highest-wealth households held steady. They increased their portfolio weights for only three asset categories: CDs, marketable bonds, and investment real estate.

For each survey date, Table 11 reports real-estate debt ratios by wealth decile. For all deciles but the third, ratios of real-estate debt to various asset values decline between 1962 and 1970. However, debt-to-income ratios behave quite differently for households in different places in the wealth distribution. For

small savers, the ratio increases sharply between survey dates. For households in the sixth through ninth wealth deciles, the ratio falls. The pattern of debt-toincome ratios observed supports the hypothesis that in 1970 low-wealth households found it necessary to leverage more of their human capital to support expansion in real-estate equity and other assets.

V. ESTIMATED 1970 WEIGHTED-AVERAGE PROSPECTIVE

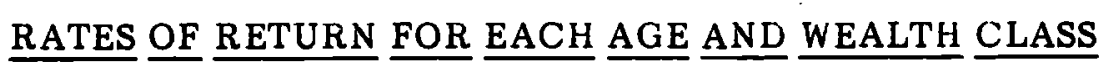

Our explanation of the changing distribution of household savings across assets presumes that households reallocate their funds as far as possible to escape the costs that accelerating inflation and deposit-rate regulation would otherwise 
impose upon them. To clarify how this process affects ex-ante portfolio returns, Table 12 uses proxies for prospective 1970 asset yields to translate the portfolio proportions underlying Tables 4 and 9 into weighted-average prospective rates of return for each age and wealth class. Because these calculations neglect discriminatory variation across wealth classes in the rates of return earned on deposits, they provide conservative estimates of the degree to which returns on financial assets differ with a household's transactable wealth and position in the life cycle. On the other hand, reporting bond values on a face-value basis systematically overweights yields on the bond portion of household portfolios. Since bond holdings tend to rise with wealth and age, at least the two biases are offsetting in direction.

Specifically, the calculations reported in Table 12 employ the following estimates of the annual average yield that might have been anticipated on individual assets in 1970:

1. Yield on Demand Deposits $=6.36$ percent $(\text { Stevens, } 1976)^{6}$

2. Yield on Savings Deposits $=\mathbf{5 . 0 6}$ percent (Table 1$)$.

3. Yield on U.S. Savings Bonds: $\mathbf{5 . 0 0}$ percent (Yield set on new U.S. savings bonds in December, 1969).

4. Yield on Other Bonds: 6.58 percent (Table 1, Long-Term Treasury Bond Yields)

5. Yield on Stocks and Mutual Funds: 8.5 percent [Mean Annual Return on Common Stocks, 1926-1974 (Ibbotson and Sinquefeld, 1976)] .

6. Yield on Equity in Home: 8.45 percent (Table 1, FHLBB Mortgage Interest-Rate Series). 
7. Yield on Equity in Investment Real Estate: 9.86 percent [Average Interest Rates on Income Property Mortgages, American Life Insurance Association, cited in Gettel (1976, p. 108)] .

Our proxies for the last four yields are chosen conservatively, especially on a before-tax basis. Yields on shorter instruments, taxable-equivalent yields on municipals, and yields on corporate bonds averaged much higher than yields on long-term U.S. governments. Moreover, although the ex post yield on stocks was only 4.01 percent in 1970 , prospective yields on common stocks almost certainly exceeded the rate of inflation. For two-year and three-year holding periods, realized per-annum yields on common-stock investments made in 1970 averaged 9.0 and 12.2 percent respectively. Over 1901-1971, Friend and Blume (1975) estimate mean per-annum yields on stocks of 9.0 percent.

Most importantly, while yields on both forms of real-estate equity should equal corresponding mortgage interest rates at the margin, prospective returns figure to be higher on average. Our estimates of prospective real-estate yields may be excessively conservative. Although a telephone survey of trade associations in St. Louis, Chicago, and Washington could uncover no direct data on realestate returns, information in the files of the General Services Administration's Appraisal Staff supports using an ex-ante per-annum return of just over 12.00 percent in 1970. Diamond (1979) estimates (net of anticipated price appreciation) a before-tax "user cost of capital" of 12.49 percent for owner-occupied housing in 1970. Hendershott and $\mathrm{Hu}(1979)$ report estimates of this cost in 1964,1972 , and 1978, for households in three different tax brackets and under two alternative models for forming expectations of future price appreciation. Hendershott and Hu's estimates range between 12 and 13 percent for households in their lowest tax bracket. 
Alternatively, a 10-percent basic rate of prospective return on housing in 1970 can be constructed as the sum of an imputed rental rate of return and an anticipated rate of housing-price appreciation. Drawing on the national-income accounts, Larry Kotlikoff of the National Bureau of Economic Research estimates (in private correspondence) that the imputed rental rate exceeded 4 percent in every year between 1962 and 1970. Over the three years preceding 1970, Commerce Department indices of housing prices increased roughly 6 percent. Factoring in the benefits of leverage easily supports a rate of return on equity of 12 percent or more.

Table 13 develops alternative, less-conservative estimates of portfolio rates of return for households in our ten wealth and six age classes. These estimates assume higher anticipated returns on other bonds ( 8 percent) and on both forms of real-estate equity (12 percent).

Under either set of assumptions, prospective 1970 yields on regulated financial assets average less than 6.00 percent. Even without formal calculations, it is obvious that overall rates of return will be highest for classes with low percentages of their transactable wealth in these assets and high percentages in unregulated assets and real-estate equity. Because deposit-rate regulation artificially restricts the explicit rewards offered on low-risk assets, households have been encouraged to occupy riskier and less-than-perfectly-diversified balancesheet positions.

Tables 12 and 13 develop two remarkable results. First, while households in the lowest deciles have simply been short-changed, households in the middle wealth deciles used investments in real estate to offset a good portion of the discriminatory effect of deposit-rate ceilings on the yields they could earn on strictly financial assets. Although differences in marginal tax rates importantly affect the desirable breakdown between prospective in-kind running yield and price 
appreciation, combined portfolio yields differ much less by wealth than financial yields do. Second, along with the very poor, young households (those whose head is under 25 years of age) emerge as the group most severely burdened by the doublewhammy of accelerating inflation and interest-rate ceilings. This may occur because these households realize a lower in-kind running yield from a given living space or because they have a hard time competing for mortgage funds, especially when state usury ceilings are binding on mortgage interest rates. Whatever the reason, unlike other age classes in 1970, young families were able to use realestate investments to eliminate only about half of the gap between the yield on their portfolio and that earned by members of the modal class.

Even the conservative estimates in Table 12 indicate that on a before-tax basis households in the middle and upper wealth classes were able in 1970-by taking on additional portfolio risk-to anticipate earning a positive real rate of return even on their financial assets. Whether after-tax real yields are positive as well depends on the breakdown of these returns between explicit running yields, implicit yields, and price appreciation. However, households in the various wealth classes reached out for this yield along different effective risk-return loci and took on quite-distinct risks. Unanticipated developments over the decade of the $1970 \mathrm{~s}$ (particularly, unanticipated inflation) made shifts into real-estate equity look even wiser ex post and movements into unregulated assets look fatuous.

\section{TESTING THE MINORITY HYPOTHESIS:}

CONSOLIDATED 1970 BALANCE SHEETS AND PROSPECTIVE PORTFOLIO

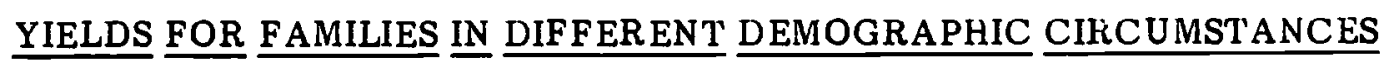

Accelerating inflation and deposit-rate ceilings tax the poor to finance "welfare" for the rest of us. In their distributional effect,they are equivalent to a confiscatory federal tax that falls on the financial wealth of sinall savers only and 
whose proceeds are designated to subsidize homebuilders, homeowners, and managers and/or stockholders of inefficient depository institutions. ${ }^{7}$

Besides stock-market investors, after-the-fact losers in the game of accelerating inflation cum deposit regulation have been families of modest means who concentrate their savings in regulated assets and/or do not own any real-estate at all. Compared to other respondents, these families are drawn disproportionately from the ranks of the black, the female, the poor, and the young. In competing for mortgages, these groups are traditionally portrayed as disadvantaged. However, deposit-interest ceilings aggravate that disadvantage by driving up both the cost of housing and demands for mortgages among other groups, while reducing the disadvantaged sectors' ability to accumulate an acceptable downpayment.

For four different demographic groups, Table 14 shows how household asset allocations and anticipated portfolio returns varied with net transactable wealth in $1970 .^{8}$ Less than ten percent of the lowest-wealth households were able to participate in real-estate ownership. They placed the bulk of their wealth in regulated assets (deposits and U.S. savings bonds). Within each group, wealthier households proved increasingly able to use both real-estate and securities investments to secure an anticipated positive net real rate of return on their overall portfolios. Interestingly, controlling for wealth and sex of head, black households show a higher propensity for real-estate investment than white families.

Distinguishing between real-property owners and nonowners in the same four demographic groups, Table 15 shows how 1970 portfolio weights and anticipated yields varied by age class. In each demographic group, the proportion of young families that own real property is low. However, because of differences in the distribution of wealth, it is almost uniformly lower for female-headed families than for male-headed families and for black families than for white ones. Controlling for the age and sex of household heads, black families show a lesser participation in real-estate ownership than white families. This occurs despite black families' 
greater propensity for real-estate ownership as shown in Table 14, because they families have disproportionately less wealth and income than white households.

For the same groups that are featured in Table 15, Table 16 presents 1970 portfolio weights and anticipated yields by household income. Households with less than $\$ 7500$ in 1970 income are about evenly divided between real-property owners and nonowners, but within this category black and female-headed families prove less likely to own real estate.

\section{SUMMIARY OF FINDINGS}

Evidence developed in this paper clarifies how in the face of comprehensive deposit-rate ceilings real estate has served as the ordinary citizen's chief hope against accelerating inflation. By expanding their proportionate holdings of real estate, households with below-average wealth were able in the late 1960s to anticipate positive real after-tax rates of portfolio return despite painful interestrate ceilings on the deposits and savings bonds in which their transactable wealth had traditionally been concentrated. By discriminatorily reducing the efficiency of financial intermediation, interest-rate ceilings have biased investments by small savers toward tangible assets (especially real estate) and investments by very large savers toward unregulated financial assets.

Although these reconstituted portfolios made sense in 1970 , they appear unnecessarily risky ex ante for both groups. With real-estate investments protected against unanticipated inflation and stocks and bonds proving surprisingly vulnerable to it, so far the nation's wealthiest households have fared less well ex post than the average homeowner. However, precisely because homeowners' portfolios of transactable wealth are protected against unanticipated inflation, they remain exposed to substantial deflation risk. As they come to realize this, homeowners may begin to function politically as an explicit constituency for inflation. 
Other remarkable findings concern the increased emphasis on leveraged housing investment among the very young. Between 1962 and 1970, households headed by persons under 25 years of age greatly expanded equity in homes, although not enough to lift estimated yields on their savings up to the level achieved by older groups. Since the implicit yield on a given home tends to increase with family size, along with older households contemporary young families may be disadvantaged in the running yields that they can earn on equity invested in homes. In addition, binding ceilings on mortgage interest rates tend to restrict young persons' ability to finance desired purchases of homes.

Our data also show that, between 1962 and 1970 , direct holdings of marketable bonds and stock have become more tightly concentrated in the hands of wealthy investors. This development supports the hypothesis that at least in 1970 only wealthy households could economically engage in strictly financial-market disintermediation. This explains why federal banking and $S \& L$ regulators settled on the strategy of relaxing deposit-rate ceilings only on ininimum-denomination and longer-maturity accounts. This approach conserves depository-institution profits by allowing them to increase the yields offered to interest-sensitive customers without simultaneously raising yields on interest-insensitive funds. However, regulators must recognize that, even among small savers, interest sensitivity tends to increase with the length of time that sizeable interest-rate differentials remain in force.

Finally, our analysis provides a more balanced perspective on the supposedly unfavorable trends of falling funds flows to traditional savings institutions and rising ratios of household debt to income. These developments reflect not profligacy but households' willingness to expose themselves to deflation risk in hopes of enhancing the real value of their accumulated savings. Aggregate 
household saving is alive and well, but it is taking some unconventional and risky forms. Miore and more, prudent households are focusing on building up a speculative investment portfolio of inflation-protected tangible assets to supplement their holdings of strictly financial assets. 
Table 2. Effective Federal Tax Rates on Equivalent Real Taxable Incomes for Households Filing Joint Returns in 1962 and 1970

\begin{tabular}{|c|c|c|c|c|c|}
\hline $\begin{array}{l}\text { Taxable } \\
\text { Income } \\
\text { in } 1970 \\
\text { Dollars } \\
\end{array}$ & $\begin{array}{c}\text { Equivalent } \\
\text { Taxable } \\
\text { Income in } \\
1962 \\
\text { Dollars } \\
\end{array}$ & $\begin{array}{c}1962 \\
\text { Miarginal } \\
\text { Tax Rate } \\
\text { on } 1962 \\
\text { Equivalent } \\
\text { Income } \\
\end{array}$ & $\begin{array}{c}1970 \\
\text { Marginal } \\
\text { Tax Rate } \\
\text { (Includes } \\
2.5 \% \\
\text { Surtax) } \\
\end{array}$ & $\begin{array}{c}1962 \\
\text { Average } \\
\text { Tax } \\
\text { Rate } \\
\end{array}$ & $\begin{array}{c}1970 \\
\text { Average } \\
\text { T'ax } \\
\text { Rate } \\
\end{array}$ \\
\hline 1,000 & 772 & .20 & .15 & .20 & .14 \\
\hline 5,000 & 3,862 & .20 & .195 & .20 & .17 \\
\hline 10,000 & 7,724 & .22 & .226 & .21 & .19 \\
\hline 20,000 & 15,448 & .30 & .328 & .24 & .22 \\
\hline 30,000 & 23,173 & .38 & .400 & .28 & .27 \\
\hline 50,000 & 38,621 & .53 & .513 & .36 & .35 \\
\hline 100,000 & 77,243 & .69 & .636 & .49 & .46 \\
\hline 500,000 & 386,214 & .90 & .718 & .78 & .66 \\
\hline
\end{tabular}

Source: Equivalent 1962 real incomes are calculated using the Implicit Price Deflator. Joint-Return tax schedules are taken from Federal Tax Handbook, 1963, Englewood Cliffs: Prentice-Hall, 1962 and 1971 U.S. Master Tax Guide, Chicago: Commerce Clearinghouse, 1970. 
Table 3. List of Variables Generated from the 1962 and 1970 Surveys of Consumer Finances for Use in This Study

Variable Name

A. Financial Assets

1. Regulated Assets

a. Checking Accounts

b. Savings Accounts

i. Certificates of Deposit

ii. Other Savings Accounts

c. U. S. Savings Bonds (Face Value)

2. Unregulated Assets

a. Stocks and Mutual Funds (Market Value)

b. Bonds other than U. S. Savings Bonds (Face Value)

i. U. S. Government Bonds

ii. Municipal Bonds

iii. Corporate Bonds

B. Real-Estate Assets

1. Home, Farm, or Mobile Home
a. Equity
b. Merket Value

2. Investment Real Estate (Including Land Contracts)

a. Equity

b. Estimated Market Value

C. Real-Estate Debt

1. Value of Mortgages on Home, Farm, or Mobile Home

2. Value of Mortgages on Investment Real Estate

D. Explicit Income in the Previous Calendar Year

1. Total Household Income

2. Capital Income (Dividends, Interest, Trust Funds, Royalties, and Rent)

a. Of Whole Household

b. Of Head Only

E. Age of Head

Variable
Symbol

Available

Available

in 1962? in 1970?

FA Calculated Calculated

RA Calculated Calculated

Yes

Yes

Yes

No

No

Yes

UA

Calculated

Yes

Calculated

Yes

Yes

Yes

Calculated

Yes

Yes

Yes

REA

Calculated

HE

HV

Yes

Yes

Yes

Yes

IRE

IRV

Yes

Yes

Yes

Yes

RED

Calculated

Calculated

Yes

Yes

Yes

Yes

$\mathrm{Y}$

Yes

Yes

YC

YCWH

Yes

No

$\mathrm{ICH}$

No

Yes

AGE

Yes

Yes 


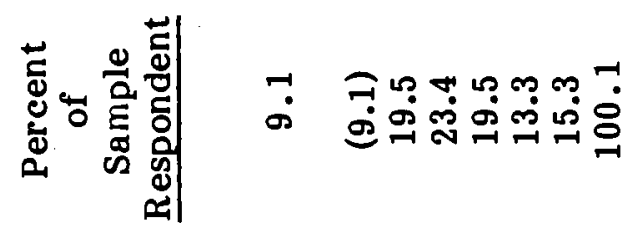

.

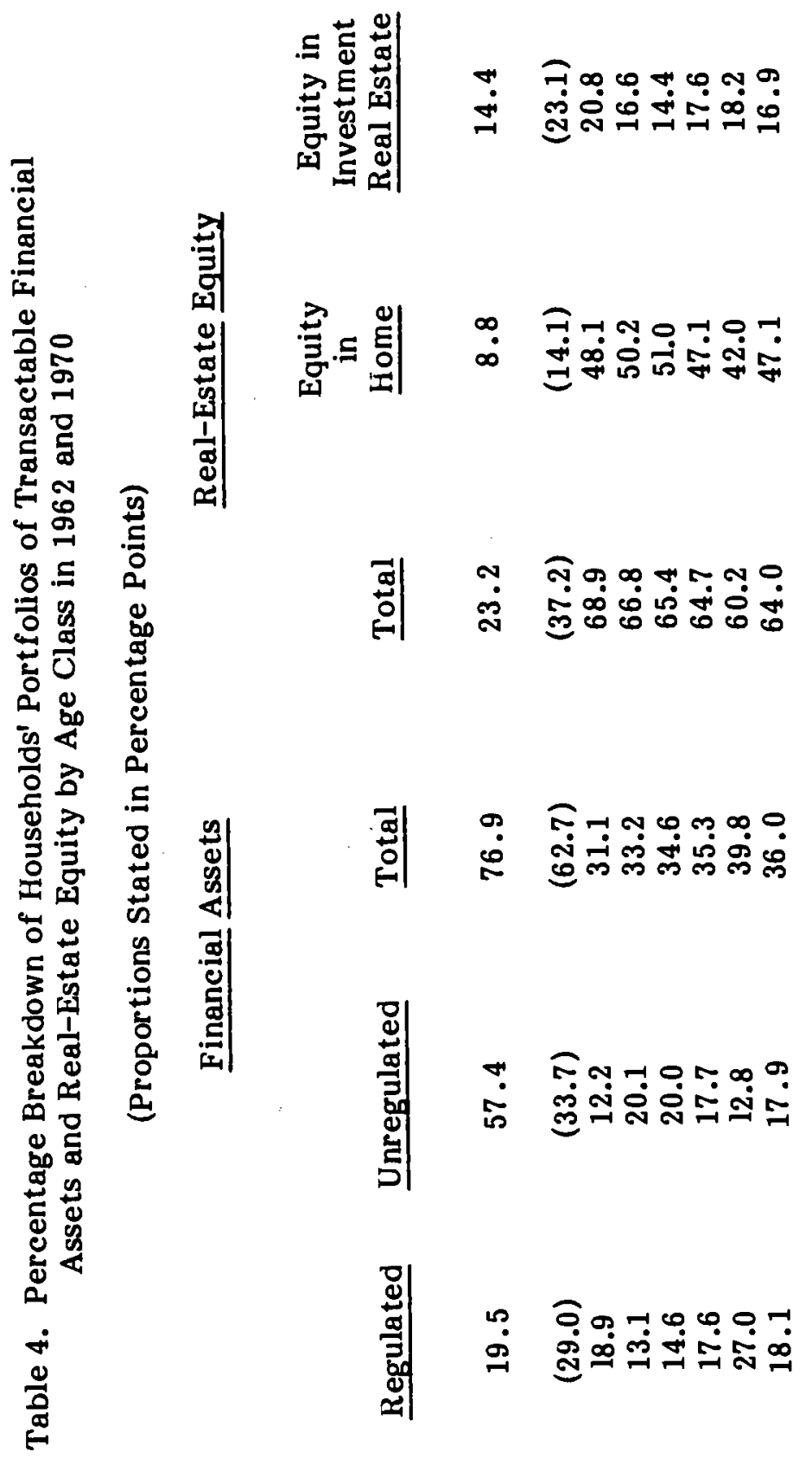

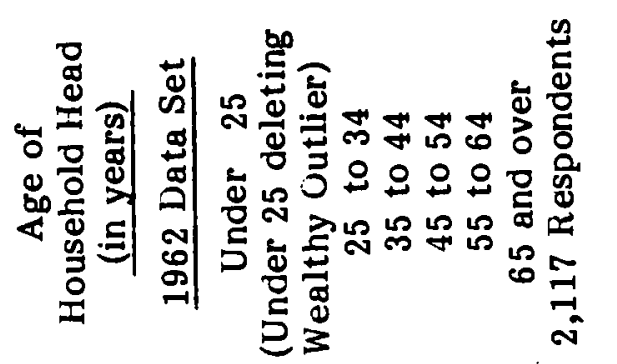

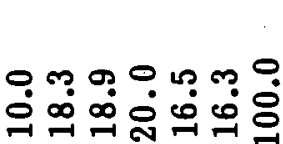

무 ๒ 임

꿍ำ

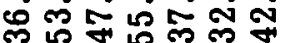

เ -1 우

แั่

的

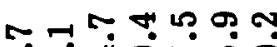
$\infty \infty \dot{⿹ 勹 冫 丿}$

$\infty$ の ๆ ஸ் 过迥車穴

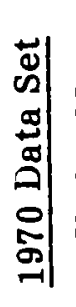

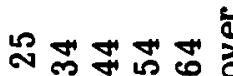
웡ㅇㅇㅇㅇㅇㅇㅇ 눈 点

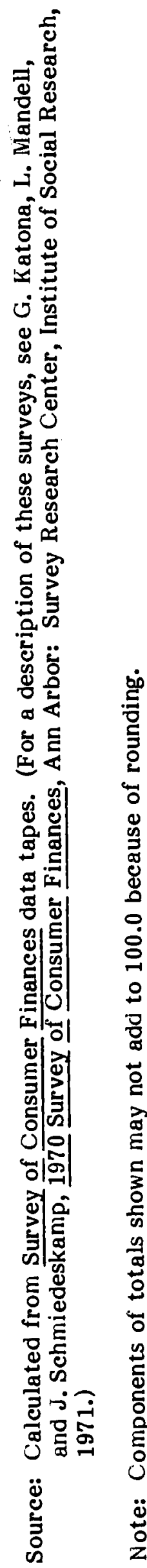




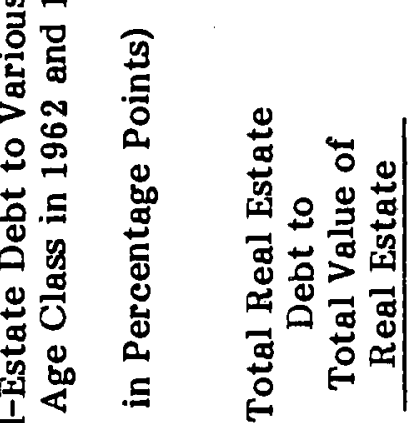

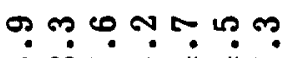

$\infty$ ๆ ๆ ๆ

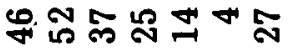

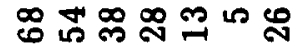

ำนกำ.

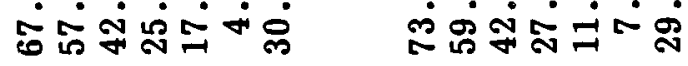

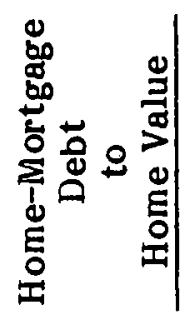

is

$\stackrel{\leftrightarrows}{\rightleftarrows}$

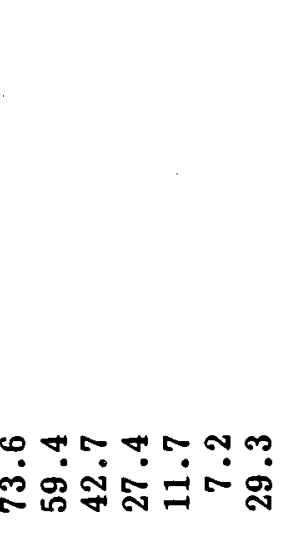




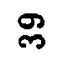
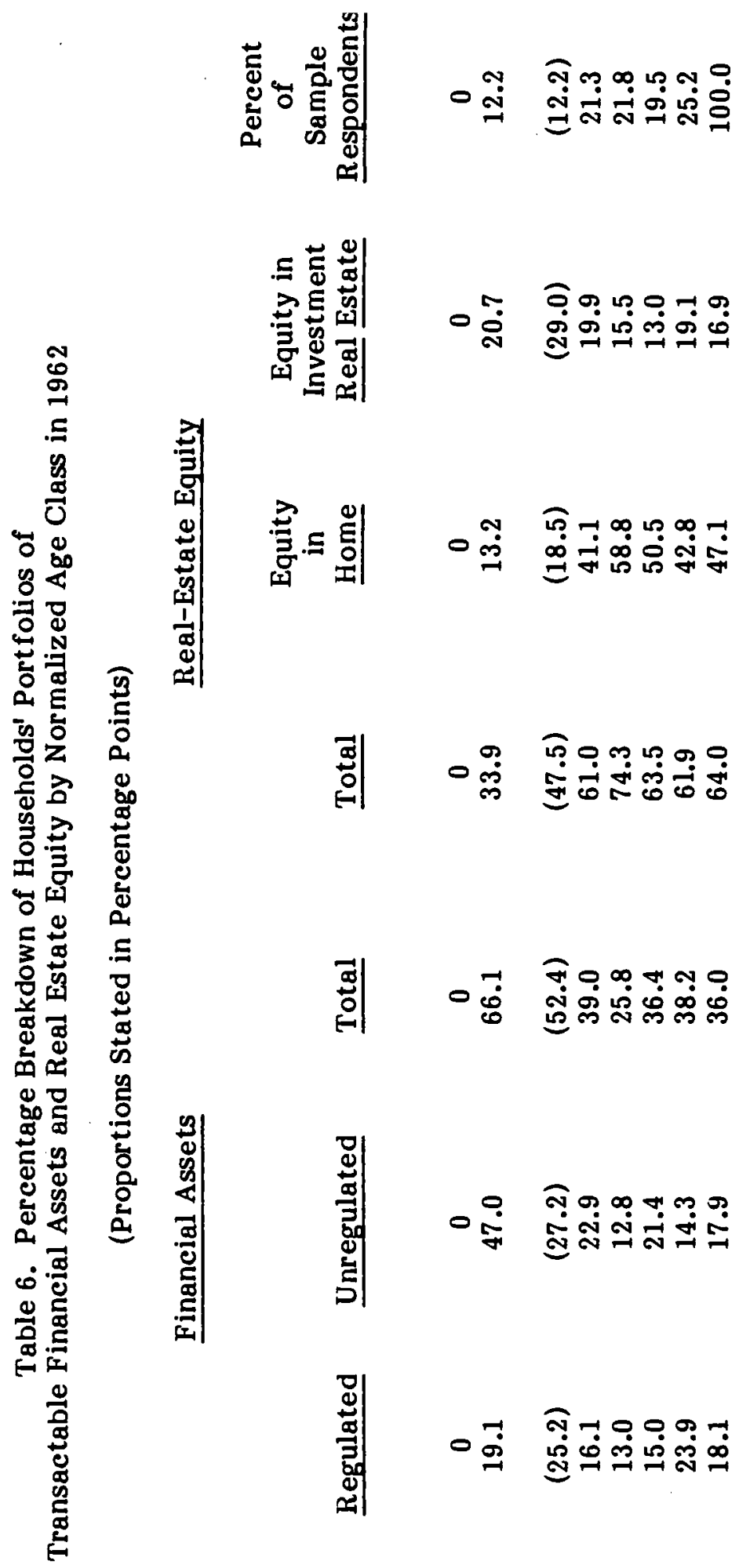

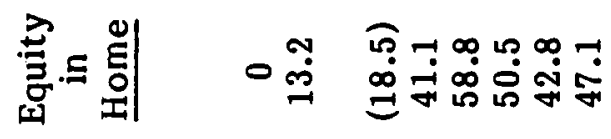

苛|

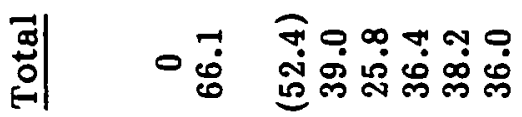

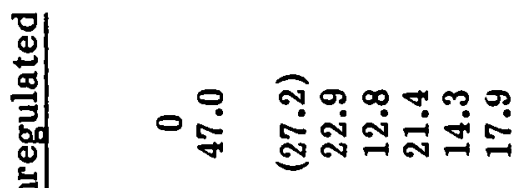

兽

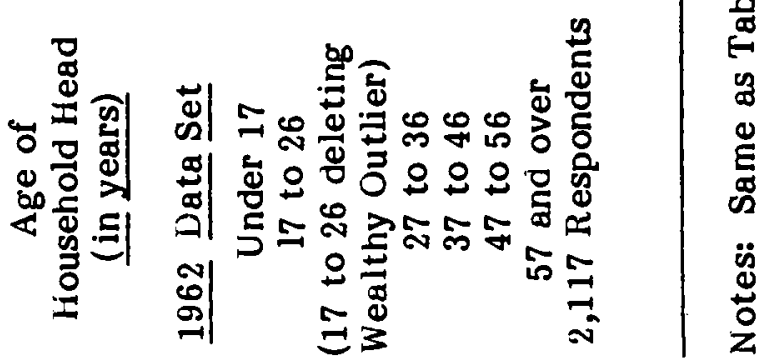




$$
\because \text { ت }
$$

$$
\text { 잉 }
$$

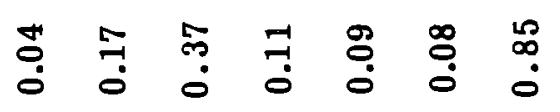

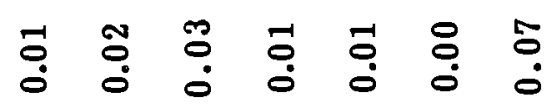

ก ก

$$
\text { ஸึ }
$$

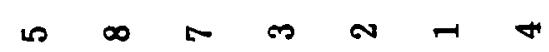

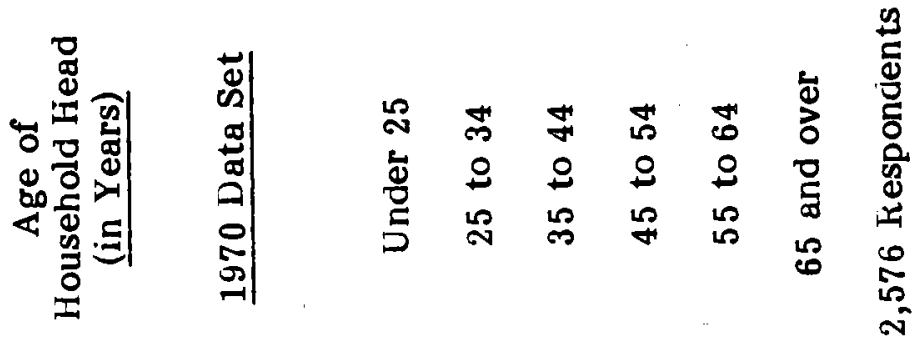


Table 8. Constructing Housing-Value

Projections That Cast Light on Aggregate Assessment Bias

\section{Year \\ in Which \\ Homeowner \\ Moved Into \\ Current Home}

$\underline{1962}$ Data Set

1939 or earlier

1940-1949

1949 or earlier*

1950-1954

$1955-1960$

1960 or earlier*

1961

1962

1970 Data Set

1945 or earlier

1946-1955

1956-1960

1960 or earlier*

1961-1965

Aggregate
Est. Value of
Homes Occupied
in Designated
Years
(in $\$$ Thousand)

Number of

Households

Moving in

During the

Designated

Years

\begin{abstract}
Average
Estimated

Value of

Designated

Homes
\end{abstract}

(in \$ thou.)

\begin{tabular}{cc} 
High & Low \\
Projection & Projection \\
of Value & of Value \\
in 1970 & in 1970 \\
(in $\$$ thou.) & (in $\$$ thou.) \\
\hline
\end{tabular}

21.96

20.43

21.08

20.78

22.98

21.80

21.89

24.00
19.47

18.11

18.69

18.43

20.38

19.32

19.40

21.28

Source: Same as Table 4

Notes: Projections for 1970 employ a cumulative growth factor generated by multiplying year-to-year changes in two "extended" indices of housing prices (U.S. Department of Commerce, 1977). The "high projection" combines the rate of increase in the GNP price deflator for 1962 and 1963 with the Commerce Department's series of changes in the average sales price of new houses actually sold in each of the years 1964 through mid-1970. The estimated cumulative inflation factor is $\mathbf{5 0}$ percent. The "low projection" replaces year-toyear changes in the prices of houses sold in each year with changes in the average sales price of the kinds of houses sold in 1974. This produces a cumulative inflation factor of only 33 percent.

The symbol * indicates observations constructed by summing aggregate values in the preceding categories. 


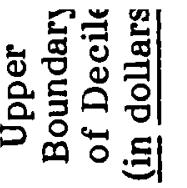

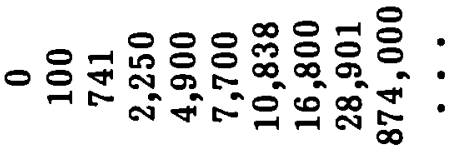

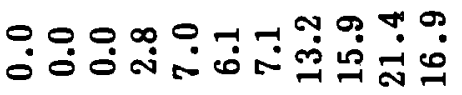

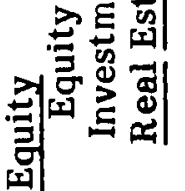

D

离

Ф웅

용

蛋

ญ

옹

政

品

$\overbrace{}^{\Phi}$

$E$

뚱

\% 氶

웅

幽

올

is

웅

ํํㄹ :

๑

เ

응 올

常

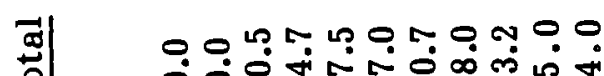
|

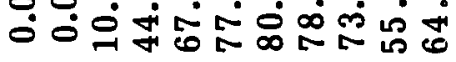

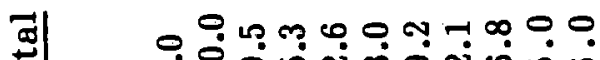

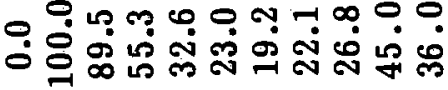

|⿹丁口

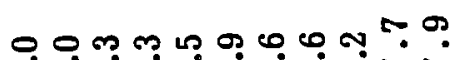

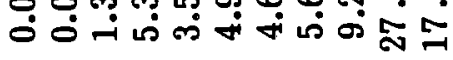

"

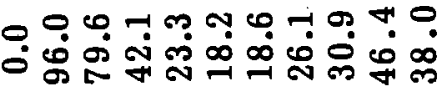

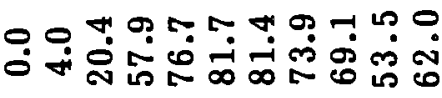

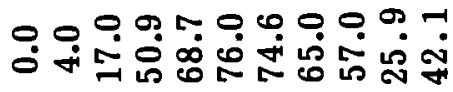

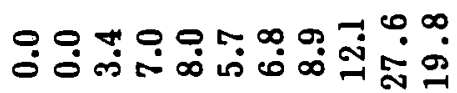

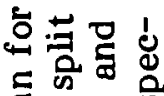

है क षे ญे

궁

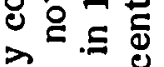

过品

己을 응

$.5 \tilde{\omega}_{\infty}^{\infty}$

ชัญ

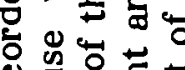

छै

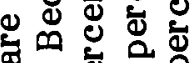

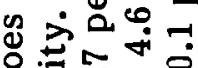

일도옹

N 걱

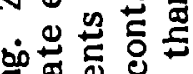

.

월을

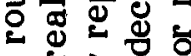

눙후을

ه

卷芯

造 $=50$

○ 음

$8 \div$ ธิ

0 क क

웡

०。

क

ㅁํㅇ

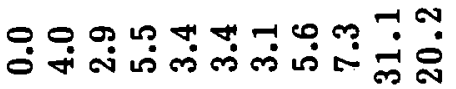

恚|

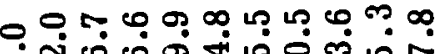

n की 을

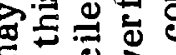

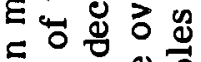

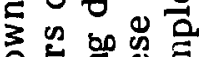

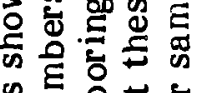

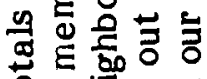

요요

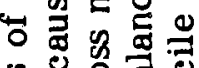

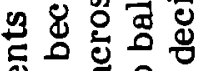

¿ ல்

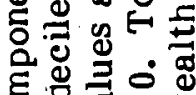

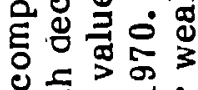

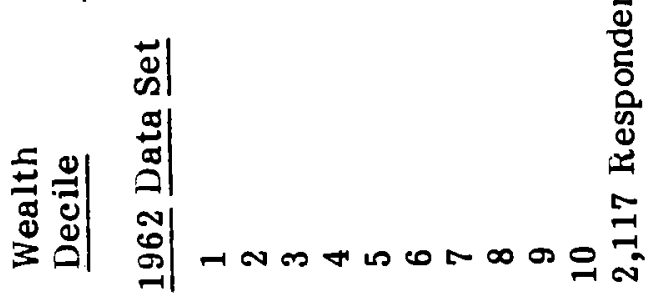

苟

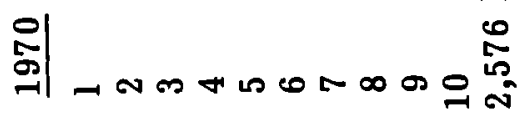


资 0 0

ง

至

m nก nothmo

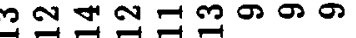
0 ór

$\stackrel{0}{\circ}$

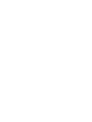




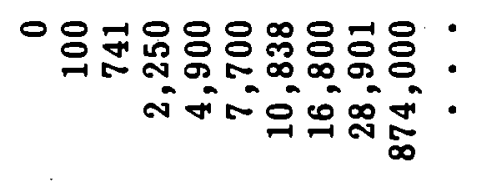

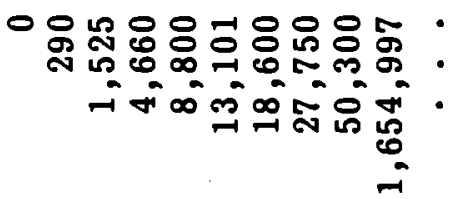

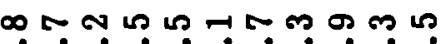

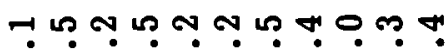

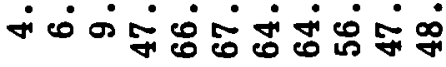

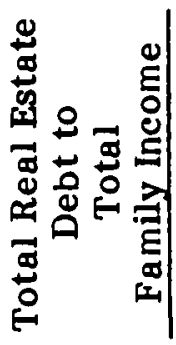

幽

进息

도 을

을 동

要

$>1$

$+\underline{9}$

웅용

\&

吕

車.

员品

$\Rightarrow+1$

要

$\stackrel{4}{4}$

융 응

응 융

อั่

곤

亗

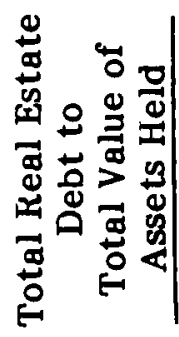

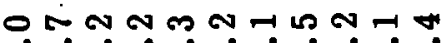

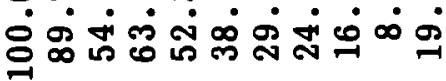

0.

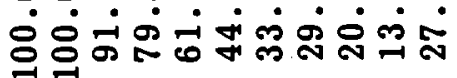

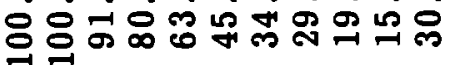

0 แ

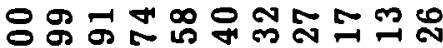

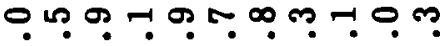

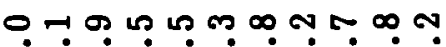
용 음

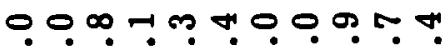
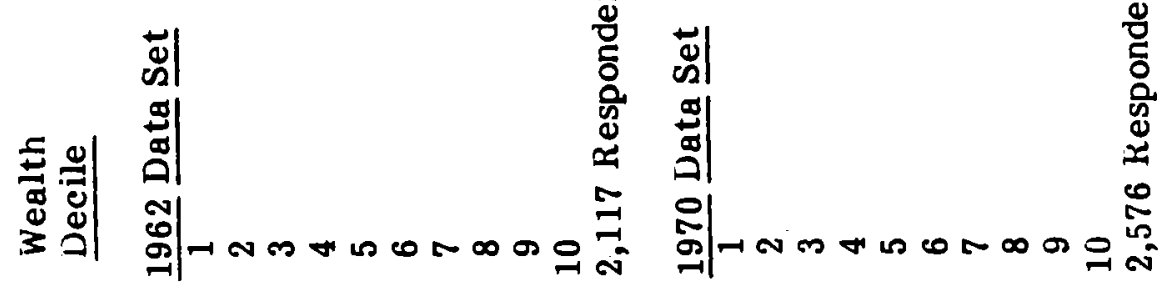

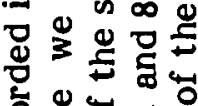

苍范亡

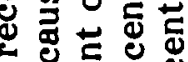

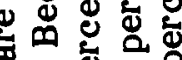

g $>\dot{\Phi}$

\&

के

N四

$\therefore \stackrel{0}{2} \stackrel{2}{5}$

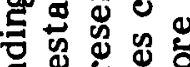

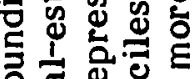

원용

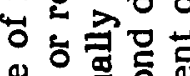

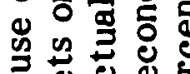

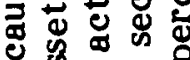

\&

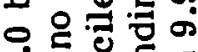

옹웡용

그응

원 包:

무요요

:

ㅇํㅇ 吾.

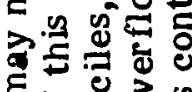

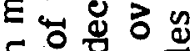

5

음

电㐫 응

온

。元的吉

曲

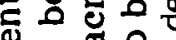

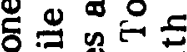

용워

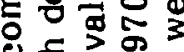

동ㄷㅁ

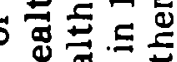

饥 300

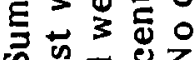

ज

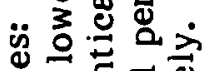

今心

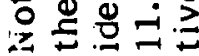


Table 12. Estimates of Prospective 1970 Portfolio Rate of Return for Each Age Class and Wealth Decile

(Stated in Percent Per Annum)

\begin{tabular}{c} 
Decile Ranking \\
of Households \\
Net Transactable \\
Wealth \\
\hline
\end{tabular}

1
2
3
4
5
6
7
8
9
10
2,576 Respondents

Age of

Household Head

(in years)

Under 25

25 to 34

35 to 44

45 to 54

55 to 64

65 and over

All Respondents
Yield on

Financial

Assets

Only

$\ddot{5} \dot{\theta}$

5.96

5.57

5.77

5.81

5.88

5.78

5.91

5.93

7.26

6.85

\author{
Combined Yield on \\ Financial Assets \\ and Real-Estate \\ Equity
}

0.06

6.21

7.42

7.95

8.06

8.05

7.91

7.84

8.29

8.12
5.81

6.20

6.86

6.46

7.10

6.88

6.85
7.18

8.09

8.32

8.19

8.11

8.00

8.12

Source: Calculated from portfolio weights underlying Tables 4 and 9, using yield assumptions stated in the text. 
Table 13. Less-Conservative Estimates of Prospective 1970 Portfolio Rate of Return for Each Age Class and Wealth Decile

(Stated in Percent Per Annum)

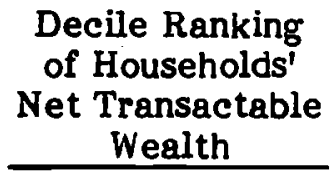

1
2
3
4
5
6
7
8
9
10
2,576 Respondents

Age of

Household Head

(in years)

Under 25

25 to 34

35 to 44

45 to 54

55 to 64

65 and over

All Respondents

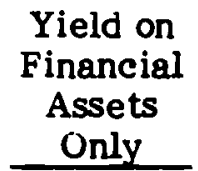

...

5.96

5.58

5.77

5.81

5.88

5.78

5.91

5.95

7.37

6.93
Combined Yield on Financial Assets and Real-Estate Equity
6.20
6.89
9.38
10.56
10.88
10.84
10.41
10.13
9.85
10.07

$\cdots$

$\begin{array}{cc}5.82 & 8.69 \\ 6.23 & 10.38 \\ 6.88 & 10.51 \\ 6.51 & 10.56 \\ 7.20 & 9.87 \\ 6.97 & 9.63 \\ 6.93 & 10.07\end{array}$

Source: Calculated from portfolio weights underlying Tables 4 and 9 , using yield assumptions stated in the text.

Note: As compared to the estimates reported in Table 12, these calculations assume higher anticipated rates of return on other bonds ( 8 percent), homeowner equity (12 percent), and equity in investment real estate (12 percent). 


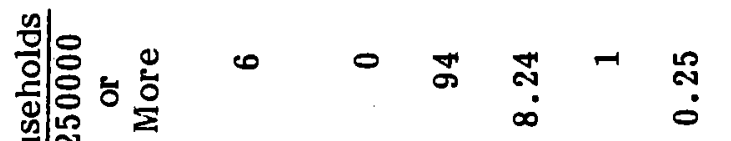

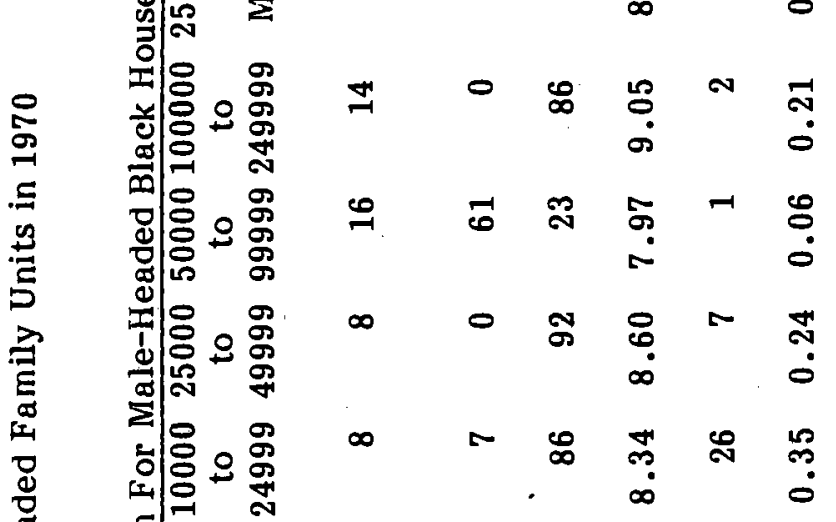

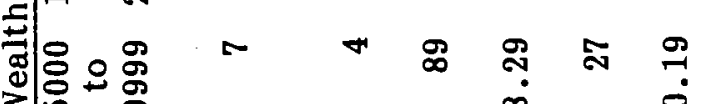

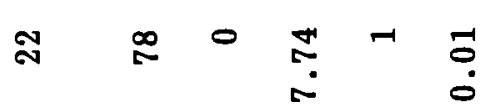

क

힌.

吾

ㄴ.

윙융 눙

ฮั

垔

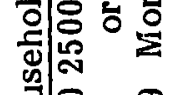

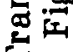

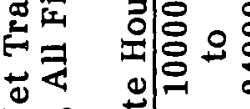

z

ธี

용요

¿

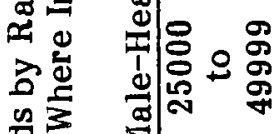

क

히용

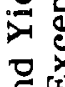

뭍ㄹㅆ

竎



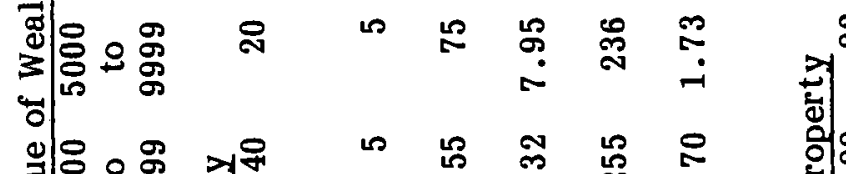

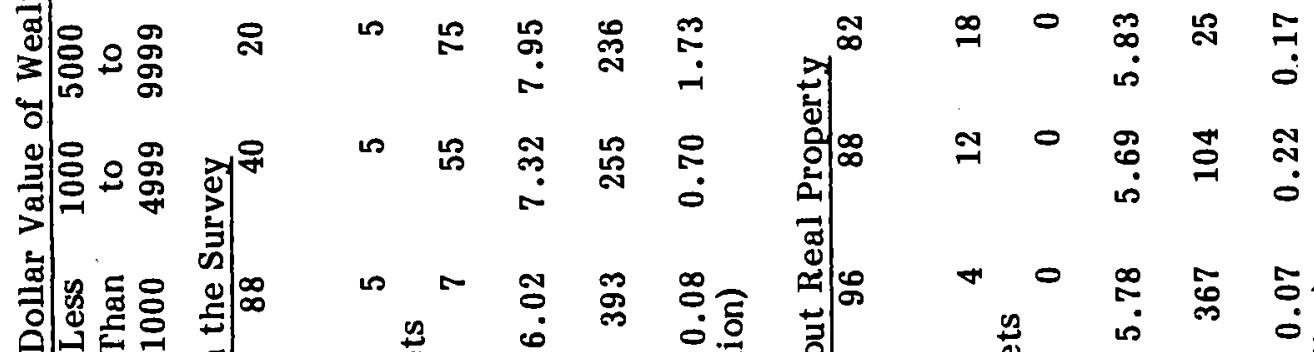

I

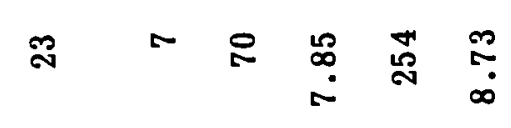

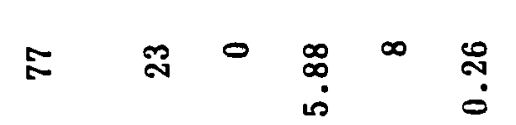

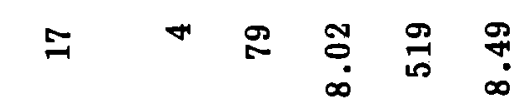

i

50 ก

莺

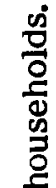




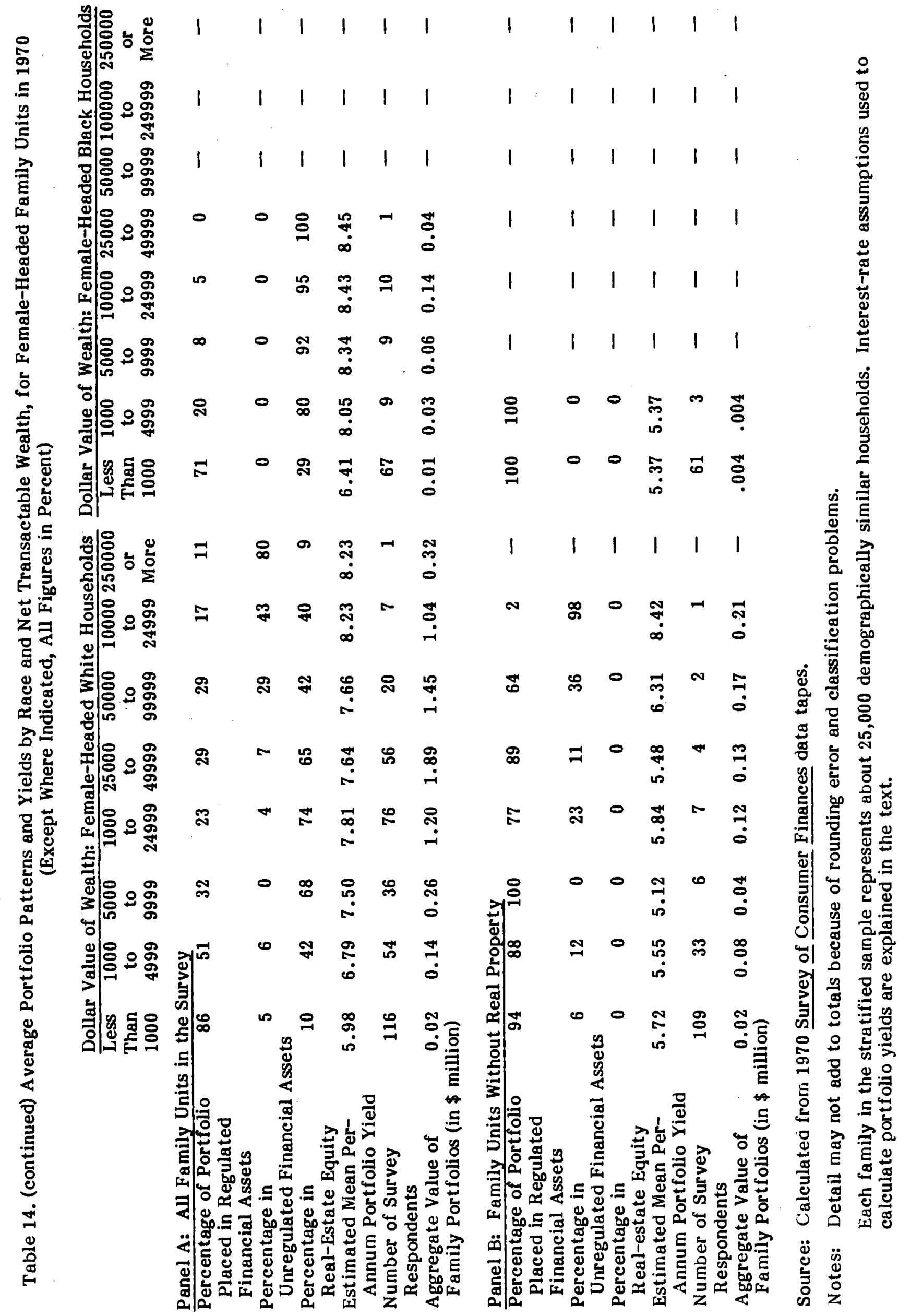




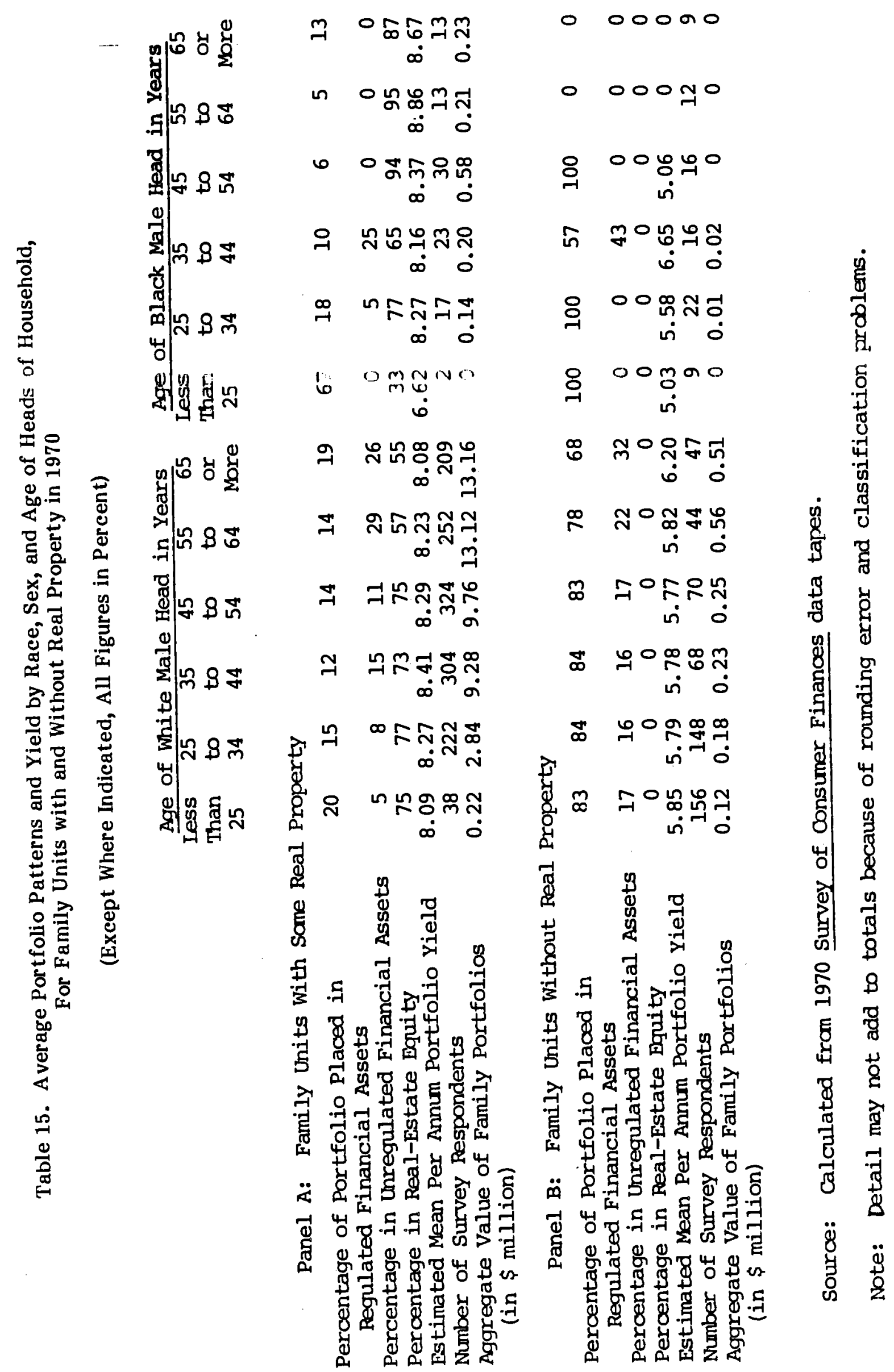


c.

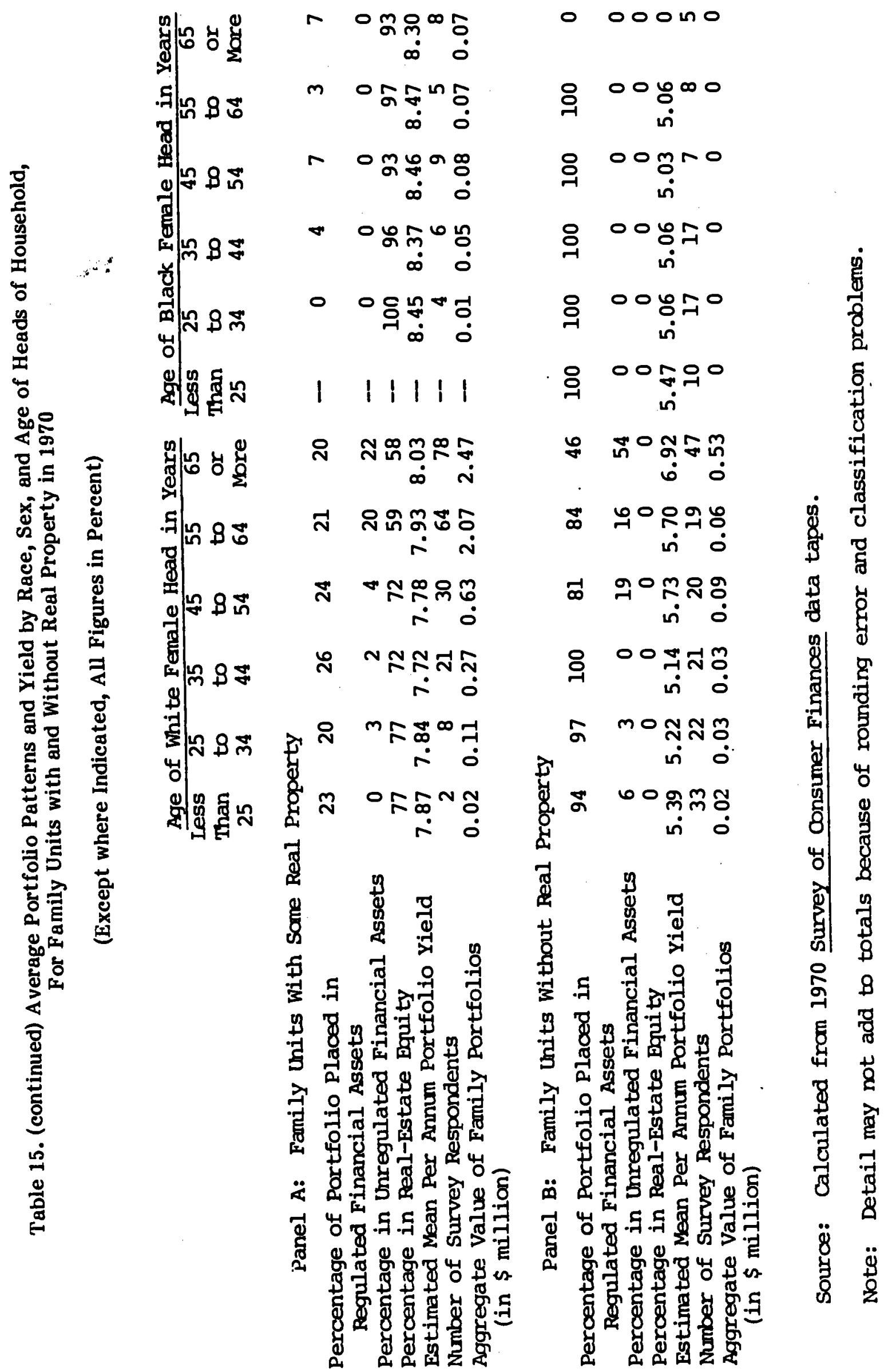


$\mid \frac{0}{0}$<smiles>[Tl]</smiles>

ठํำ

i

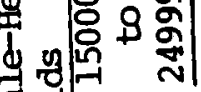

岁题遂 9 命

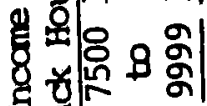

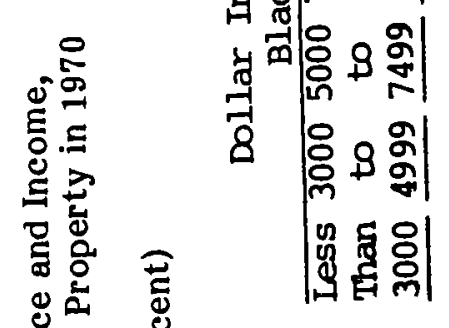

政

赵

\section{긍 \\ 可}

\section{的}

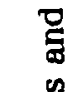

这

告

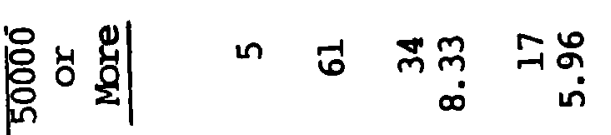

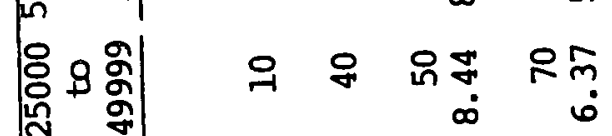

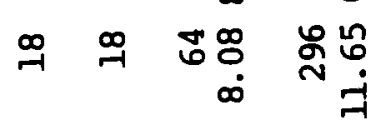

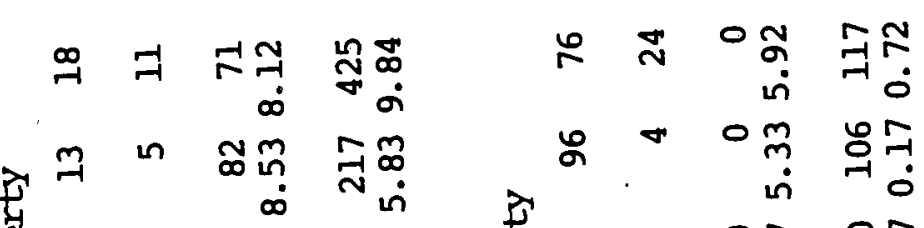

岁歌 \&

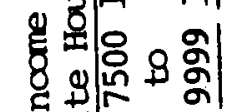

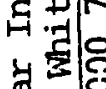

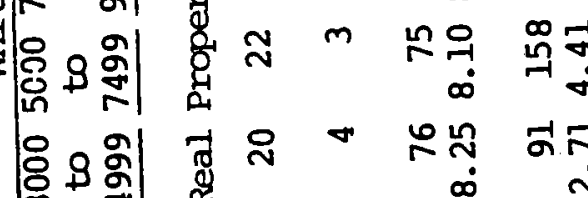

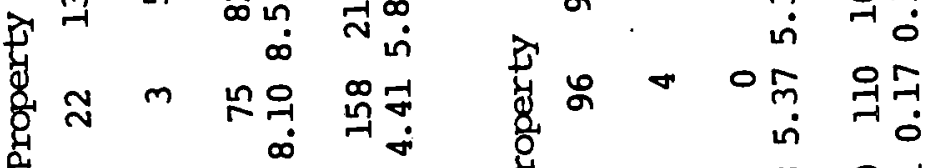

ส요

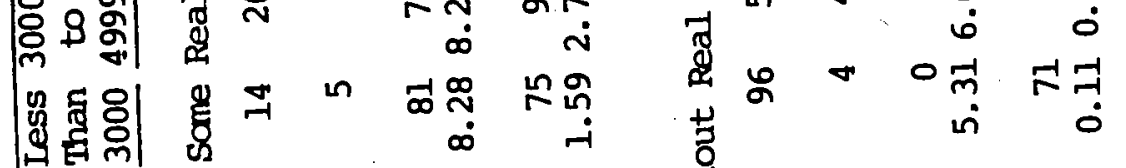

急.

素要表

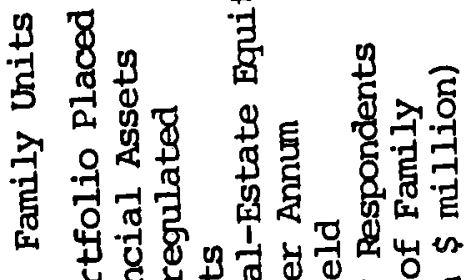

范等5

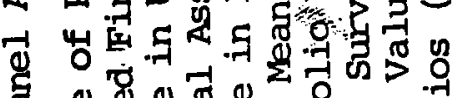

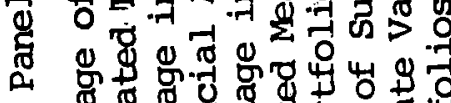

If

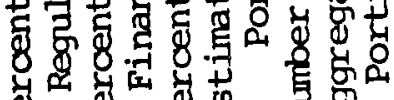

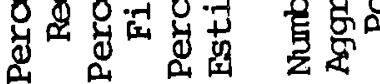

牙年

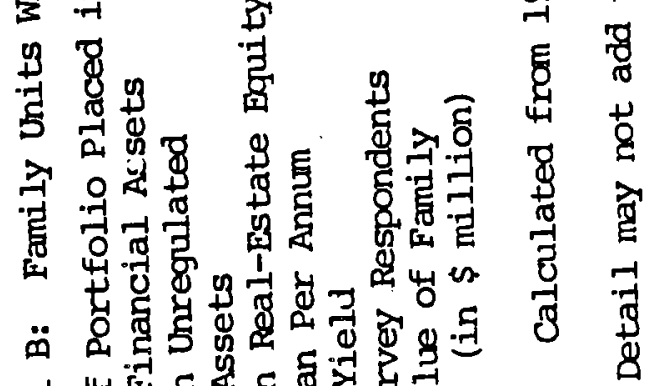

- 4 出 5 .

g o

Is

$\begin{array}{ll}\ddot{8} & \\ \vdots & 0 \\ 0 & 0 \\ 0 & 0\end{array}$

சृ

章

है

㟧 8

के

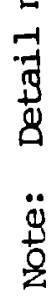




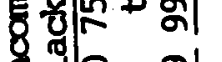

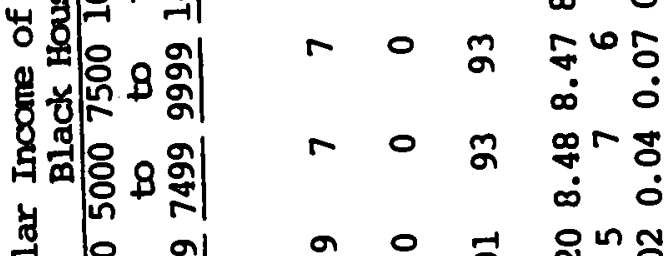

111111

\& 0 Ọ

४

- 0 \&

- 000 no

员 象

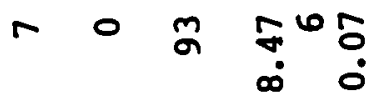

总

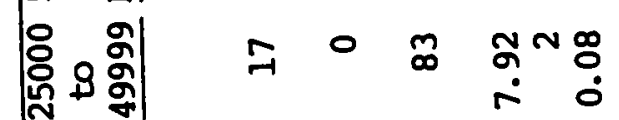

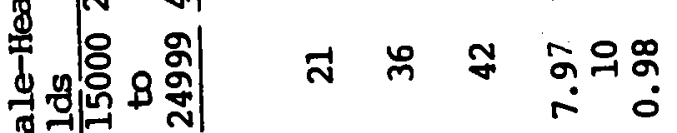

岁

ก ก ํำ 춘ำ

$0000-10$

\&0 0\%

○ 0 ○ீ

\& $00 \underset{j}{0} \tilde{m}^{\circ}$

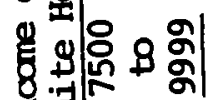
$\therefore 0$

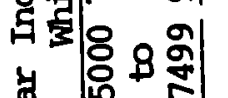

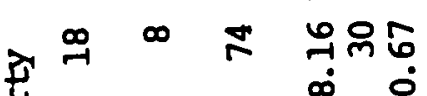

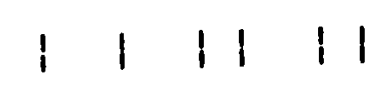

개요

111111

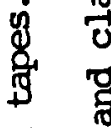

न

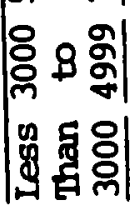

ก $ก$ เ

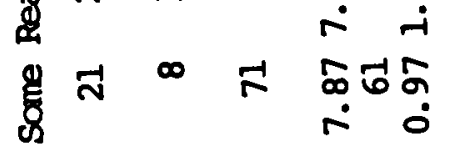

章.

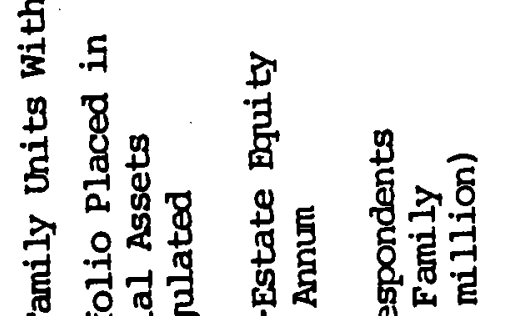

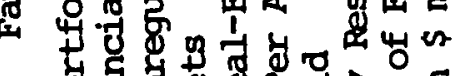

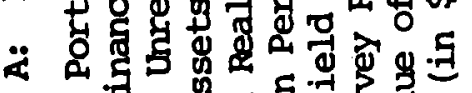

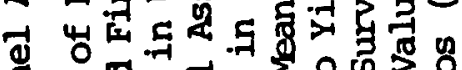

ᄃ

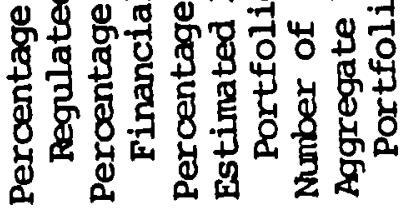

ヘ ๑

1 잉

ก $\pi$ 용 กั

要 


\section{FOOTNOTES}

*'The author, who is Everett D. Reese Professor of Banking and Mionetary Economics at The Ohio State University, wishes to thank Alexander J. Shumay for skillful and painstaking research assistance and the Inter-University Consortium for Political and Social Kesearch for furnishing Survey of Consumer Finances data. Data-processing took place mainly via IBM 370 programs written by Mr. Shumay. This paper extends and substantially refocuses an earlier study (Kane, 1980). For detailed criticism of earlier drafts, the author is grateful to Phillip Cagan, Dennis Draper, Benjamin Friedman, John McConnell, Joseph Minarik, John Tuccillo, and George von Furstenberg and to seminar audiences at The Federal Reserve Bank of St. Louis, The Georgia Institute of Technology, Michigan State University, The National Bureau of Economic Research (Cambridge), The University of Washington, Western Michigan University, and The University of Wisconsin, Madison.

Finally, the research reported here is part of the NBER's research on The Changing Roles of Debt and Equity in Financing U.S. Capital Formation. The author wishes to thank the U.S. Departinent of Housing and Urban Development and The Ohio State University Center for Real Estate Education and Research for financial support. All opinions expressed are those of the author and not those of the NBER or any sponsoring agency.

${ }^{1}$ Between 1962 and 1970 , net acquisition of claims on pension funds averaged a fairly steady 22 percent of household asset acquisitions. Year by year, this proportion varied only between 20 and 24 percent. Net acquisitions of consumer durables averaged about 29 percent of household acquisitions, and the proportion ranged year by year between 21 and 36 percent.

${ }^{2}$ Katona et al. (1963 and 1971) reproduce copies of the survey instruments. As explained by Hansmire (1976) the SCF was discontinued after 1970. Her essay includes a summary statement of just what variables were measured in each year. Under the sponsorship of the three federal banking agencies, the Survey Kesearch Center conducted a partly similar Consumer Credit Survey in 1977. In future research, I plan to compare changes in household balance sheets across the three survey dates.

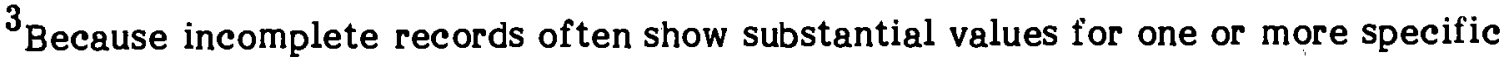
categories of assets, in compiling portfolio distributions, we chose to treat missing values as true zeroes.

${ }^{4}$ It is interesting to note that in 1978 federal tax law was changed to increase the special tax forgiveness for capital gains on sales of personal residences by older taxpayers from $\$ 35,000$ to $\$ 100,000$ and the minimum age for qualifying for this benefit was lowered from 65 to 55 . To secure this change, older households (especially those in the 55-to-64 age class) must have complained bitterly about the government's growing tax take on these transactions. 
5 To communicate the types of quality improvements that are occurring, Harter (1979) reports that between 1970 and 1977 new one-family houses increased in size and amenities. The median square footage increased from 1510 square feet to 1720 square feet, while the percentage of homes that included each of the following features increased as follows: a dishwasher (from 42 percent to 82 percent); two or more bathrooms (from 48 to 70 percent); one or more fireplaces (from 35 to 61 percent); and a garage (from 58 to 68 percent).

${ }^{6}$ of the four financial yields we estimate, this is the only one that features an implicit component. We treat this series asymmetrically because implicit returns dominate competition for demand deposits.

7 In the case of mutual institutions, availability of these subsidies may have intensified managerial incentives for converting to a stock charter.

${ }^{8}$ Our analysis of minority portfolios ignores a relatively small number of disparate nonwhite respondents who are nonblack. 


\section{REFERENCES}

1. AARON, HENRY. "Income Taxes and Housing," American Economic Review, Dec. $1970,60(5)$, pp. 789-806.

2. ARCELUS, FRANCISCO, and MELTZER, ALLAN H., "The Markets for Housing and Housing Services," Journal of Money, Credit and Banking, 5 (February 1973), pp. 78-99.

3. BOSKIN, MICHAEL J. "Taxation, Saving, and the Rate of Interest," Journal of Political Economy; April 1978, Part 2, 86 (2), pp. S3-S27.

3. CAGAN, PHILLIP, and LIPSEY, ROBERT E., The Financial Effects of Inflation, Cambridge: Ballinger Publishing Company for The National Bureau of Economic Research, 1978.

4. DIAMOND, DOUGlaS B., Jr., "Taxes, Inflation, Speculation and the Cost of Ownership: 1963-1978," paper presented before the American Real Estate and Urban Economics Association, May 23, 1979.

5. FAMA, EUGENE F., and SCHWERT, G. WILLIAM. "Asset Returns and Inflation," Journal of Financial Economics, 5 (November 1977), pp. 115-146.

6. FISHER, IR VING. The Theory of Interest. New York: Macmillan, 1930.

7. FRIEND, IRWIN AND BLUME, MARSHALL E. "Short Run Asset Effects on Household Saving and Consumption: The Cross-Section Evidence," American Economic Review, Sept. 1975, 65 (4), pp. 624-33.

8. GETTEL, RONALD E. Real Estate Guidelines and Rules of Thumb. New York: MeGraw-Hill, 1976 .

9. GURLEY, JOHN G. and SHAW, EDWARD S. Mloney in a Theory of Finance. Washington: Brookings Institution, 1960.

10. HANSMIRE, EVELYN. "Survey Data Available from the Economic Behavior Archive," in "Surveys of Consumers, 1974-1975. Edited by RICHARD T. CURTIN. Ann Arbor: University of Michigan Institute for Social Research, 1976, pp. 285-312.

11. HARTER, THOMAS R. "Housing Outlook 1979," New York: Mortgage Bankers Association of America (mimeographed, 1979).

12. HENDERSHOTT, PATRIC, and HU, SHENG CHENG, "Inflation and the Benefits from Owner-Occupied Housing," paper presented before the American Real Estate and Urban Economics Association, May 23,1979.

13. HOWREY, E. PHILlIP AND HYMANS, SAUL H. "The Measurement and Determination of Loanable Funds Saving," Brookings Papers on Economic Activity, 1978, (3), pp. 655-705. 
14. IBBOTSON, ROGER G. and SINQUEFELD, REX A. "Stocks, Bonds, Bills, and Inflation: Year-by-Year Historical Returns (1926-1974)," Journal of Business, Jan. 1976, $\underline{49}$ (21), pp. 11-47.

15. KANE, EDWARD J. "Short-Changing the Small Saver," Journal of Money, Credit, and Banking, Nov. 1970, 2 (4), pp. 513-522.

16.

- "Good Intentions and Unintended Evil: The Case Against Selective Credit Allocation," Journal of Money, Credit, and Banking, Feb. 1977, $\underline{9}$ (1), pp. 55-69.

17.

- "Consequences of Contemporary Ceilings on Mortgage and Deposit Interest Rates for Households in Different Economic Circumstances," in The Government and Capital Formation. Edited by George M. von Furstenberg. Cambridge, MA: Ballinger, 1980 (for thcoming).

18. KATONA, GEORGE, LININGER, CHARLES A. AND KOSOBUD, RICHARD F. 1962 Survey of Consumer Finances. Ann Arbor: University of Michigan Institute for Social Research, 1963.

19. KATONA, GEORGE, MANDEL, LEWIS AND SCHMIEDESKAMP, JAY. 1970 Survey of Consumer Finances. Ann Arbor: University of Michigan Institute for Social Research, 1971.

20. MiULLINEAUX, DONALD J. "Deposit-Fiate Ceilings and Noncompetitive Bidding for U.S. Treasury Bills," Journal of Money, Credit and Banking, 5 (February 1973), pp. 201-212.

21. NATHAN, HAROLD C. "Economic Analysis of Usury Laws: A Survey, Washington: Federal Deposit Insurance Corporation Working Paper No. 78-7 (mimeographed, 1978).

22. SOWELL, THOMAS. Race and Economics. New York: David McKay Company, Inc., 1975.

23. STEVENS, EDWARD J. "Measuring the Service Return on Demand Deposits, Federal Reserve Bank of Cleveland Working Paper No. 7601, (Mimeographed, 1976).

24. U.S. DEPARTMENT OF COMMERCE, Bureau of the Census, Construction Reports: Price Index of New One-Family Houses Sold, Quarterly, December $\overline{1977 .}$

25. WACHTEL, PAUL. "Inflation, Uncertainty, and Saving Behavior Since the Mid-1950s," Explorations in Economic Research, Fall 1977, 4 (4), pp. 558-78. 